\title{
The annual cycle of hydrogen peroxide: an indicator of chemical instability?
}

\author{
R. W. Stewart \\ NASA Goddard Space Flight Center, Greenbelt, MD 20771, USA \\ Received: 11 March 2004 - Published in Atmos. Chem. Phys. Discuss.: 6 April 2004 \\ Revised: 9 June 2004 - Accepted: 21 June 2004 - Published: 25 June 2004
}

\begin{abstract}
A box model has been used to study the annual cycle in hydrogen peroxide concentrations with the objective of determining whether the observed difference in summer and winter values reflects instability in the underlying photochemistry. The model is run in both steady-state and timedependent modes. The steady-state calculations show that, for some range of $\mathrm{NO}_{\mathrm{x}}$ background levels, two stable solutions to the continuity equations exist for a period of days in spring and fall. The corresponding time-dependent model indicates that, for sufficiently high background $\mathrm{NO}_{\mathrm{x}}$ concentrations, the spring and fall changes in $\mathrm{H}_{2} \mathrm{O}_{2}$ concentration may be interpreted as a forced transition between the two underlying stable regimes. The spring transition is more rapid than that in fall, an asymmetry that becomes more marked as background $\mathrm{NO}_{\mathrm{x}}$ increases. This asymmetry is related to the different time scales involved in chemical production and loss of $\mathrm{H}_{2} \mathrm{O}_{2}$. Observations of the spring increase in $\mathrm{H}_{2} \mathrm{O}_{2}$ concentration may therefore provide a better measure of the change in the underlying chemical regime than does the fall decrease. The model results developed in this paper will be compared with two sets of observations that cover annual variations of peroxide concentrations under different background pollution conditions.
\end{abstract}

\section{Introduction}

Several publications (e.g. White and Dietz, 1984; Stewart, 1993; Kleinman, 1994) have shown that the continuity equations that describe tropospheric photochemistry can exhibit bifurcations and consequent multiple steady-state solutions. These phenomena occur in the transition region between what may be characterized as low- $\mathrm{NO}_{\mathrm{x}}$ and high- $\mathrm{NO}_{\mathrm{x}}$ chemical regimes. It is not known whether these mathematical

Correspondence to: $\mathrm{R}$. W. Stewart

(Richard.W.Stewart@nasa.gov) properties exhibited by steady-state models correspond to observable phenomena in the time-dependent world. This paper addresses the question of observable consequences.

Steady-state and time-dependent calculations over an annual cycle are carried out showing that bifurcations in the steady-state solutions have an analogue in the time- dependent case. Above a certain background $\mathrm{NO}_{\mathrm{x}}$ level rapid changes in oxidant concentrations occur in time-dependent calculations. These correspond to bifurcations in the steadystate case. The rapidity of the transition increases with increasing background $\mathrm{NO}_{\mathrm{x}}$.

It is obvious that such transitions do not occur on the global scale, a predominately low- $\mathrm{NO}_{\mathrm{x}}$ environment. Their importance lies in the fact that, should they occur on more polluted regional scales, they can involve large changes in oxidant levels with a corresponding change in pollutants over a short time period of several days. Hydrogen peroxide, the focus of the discussion in this paper is an especially sensitive indicator of the low- $\mathrm{NO}_{\mathrm{x}}$, high- $\mathrm{NO}_{\mathrm{x}}$ transition.

\subsection{The observed annual cycle of $\mathrm{H}_{2} \mathrm{O}_{2}$}

This paper will discuss the annual cycle of $\mathrm{H}_{2} \mathrm{O}_{2}$ in the context of the low- $\mathrm{NO}_{\mathrm{x}}$ and high- $\mathrm{NO}_{\mathrm{x}}$ chemical regimes described by Kleinman (1991). A basic difference in these regimes is the concentration and fate of oxidants. In the high$\mathrm{NO}_{\mathrm{x}}$ regime $\mathrm{OH}$ reacts predominantly with $\mathrm{NO}_{2}$ to form nitric acid. Nitric acid is mostly removed by deposition before it can react to return its components to the atmosphere and its formation is thus a permanent loss for odd hydrogen $\left(\mathrm{HO}_{\mathrm{x}}=\mathrm{OH}+\mathrm{HO}_{2}\right)$. Since $\mathrm{H}_{2} \mathrm{O}_{2}$ is formed through reaction of two $\mathrm{HO}_{2}$ radicals it is particularly sensitive to the changes in concentration of $\mathrm{HO}_{\mathrm{x}}$ components that occur in the transition from low- $\mathrm{NO}_{\mathrm{x}}$ to high- $\mathrm{NO}_{\mathrm{x}}$ conditions. We will explore the possibility that observed mixing ratio changes in the tropospheric boundary layer might, under some circumstances, be interpreted as resulting from instability in the underlying 
steady-state chemistry. Due to the sensitivity of hydrogen peroxide to such instability it is reasonable to concentrate on its annual cycle.

Most measurements of $\mathrm{H}_{2} \mathrm{O}_{2}$ have been made over relatively limited time spans (see the review by Lee et al. (2000)). Measurements of peroxide over an annual cycle have been made by Ayers et al. (1996) at Cape Grim, Tasmania (41 $\left.{ }^{\circ} \mathrm{S}\right)$ and Sakugawa and Kaplan (1989) in and near Los Angeles, CA. The Ayers et al. (1996) measurements are of $\mathrm{H}_{2} \mathrm{O}_{2}$ plus organic peroxide and represent unpolluted marine air. They show monthly means varying from 0.16 to $1.4 \mathrm{ppb}$. The Sakugawa and Kaplan measurements of $\mathrm{H}_{2} \mathrm{O}_{2}$ were carried out in a more polluted environment. Measurements of Gnauk et al. (1997) were carried out over a 3-year period, but are only reported for selected days or over short intervals. Peroxide observations were made over a four-month period during the Tropospheric Ozone Production about the Spring Equinox (TOPSE) experiment (Snow et al., 2003). Although this time period is of special interest to the present study, the $\mathrm{NO}_{\mathrm{x}}$ mixing ratios were too low to contribute to low to high$\mathrm{NO}_{\mathrm{x}}$ transitions (Snow et al., 2003; Tie et al., 2003).

The body of observations covers different locations and times of year and is useful for deducing general characteristics of the annual cycle of $\mathrm{H}_{2} \mathrm{O}_{2}$. The property of the $\mathrm{H}_{2} \mathrm{O}_{2}$ annual cycle of most interest in this study is the change from a winter minimum to a summer maximum under various levels of background pollution as represented by the $\mathrm{NO}_{\mathrm{x}}$ mixing ratio. The annual cycle observations of Ayers et al. (1996) and Sakugawa and Kaplan (1989) are most relevant to this study and will be discussed after model results are presented.

\subsection{Nonlinearities}

The nonlinearity of the continuity equations describing atmospheric photochemistry gives rise to a number of interesting consequences. This paper will focus on multiple solutions in tropospheric models, but these have also been discussed with regard to the stratosphere (Prather et al., 1979; Fox et al., 1982; Konovalov et al., 1999) and mesosphere (Yang and Brasseur, 1994).

A relatively simple consequence of nonlinearity that has been discussed in the context of tropospheric models for some time is "turnaround" behavior. This refers to a change in sign of the rate of change of a species concentration, such as ozone, with respect to a monotonically changing control parameter, such as a nitric oxide source. Stewart et al. (1977) described the change in $\mathrm{O}_{3}$ response with increasing $\mathrm{NO}_{\mathrm{x}}$ emission. They showed that $\left[\mathrm{O}_{3}\right]$ first increased, then decreased as NO emission increased, with a turnaround occurring when the $\mathrm{NO}_{\mathrm{x}}$ background reached roughly $500 \mathrm{ppt}$. Hameed et al. (1979) discussed the importance of the $\mathrm{NO}_{\mathrm{x}}$ background on $\mathrm{OH}$ behavior and on the effect of increased $\mathrm{CO}$ source levels in the troposphere. The hydroxyl radical, like ozone, exhibits a turnaround as we go from a low to a high- $\mathrm{NO}_{\mathrm{x}}$ background. It was shown that an increasing $\mathrm{CO}$ source could either increase $\mathrm{OH}$ and decrease $\mathrm{CH}_{4}$ or have the opposite effect as $\mathrm{NO}_{\mathrm{x}}$ background changes. Poppe et al. (1993) discussed the nonlinear $\mathrm{OH}$ response to changes in several model parameters.

White and Dietz (1984) were the first to describe a more startling aspect of nonlinearity in a tropospheric model, the existence of multiple steady states. These authors showed that the $\mathrm{NO}_{\mathrm{x}}$ removal rate is a non-monotonic function of $\mathrm{NO}_{\mathrm{x}}$ concentration. This implies that multiple concentration values can exist over a critical range of $\mathrm{NO}_{\mathrm{x}}$ emission rates. Stewart $(1993,1995)$ described methods for computing multiple solutions and exhibited them for a variety of assumptions regarding both the reactions included in a model and the source values for key species. Multiple solutions occur when a control parameter, typically NO source, is varied past a critical value at which a bifurcation from one to three solutions occurs. Further variation in the same direction leads to another bifurcation in which the number of solutions is reduced to one. These bifurcation points bound a bistable region in the state space of the system, i. e., a region in which two stable steady states exist. It has not been clear how, or if, the bistability exhibited in simple models relates to observable phenomena. Kleinman (1991) suggested that the difference in summer and winter $\mathrm{H}_{2} \mathrm{O}_{2}$ concentrations observed in the northeastern United States might reflect the difference in underlying low- $\mathrm{NO}_{\mathrm{x}}$ (summer) and high- $\mathrm{NO}_{\mathrm{x}}$ (winter) photochemical states. Jacob et al. (1995) suggest that measurement of $\mathrm{H}_{2} \mathrm{O}_{2}$, and several other species, show evidence of a September transition from low- $\mathrm{NO}_{\mathrm{x}}\left(\mathrm{NO}_{\mathrm{x}}\right.$-limited) to high$\mathrm{NO}_{\mathrm{x}}$ (hydrocarbon-limited) conditions. Their data, along with other observations noted in the paper, suggest a roughly factor of 5 decrease in $\mathrm{H}_{2} \mathrm{O}_{2}$ during September.

\subsection{Chemical instability}

The terms "chemical instability" and "unstable solution" are used throughout this paper. Both steady-state and timedependent solutions of continuity equations are presented to illustrate the phenomena described by these terms and possible atmospheric consequences of such phenomena. For corresponding parameter values, the steady-state solutions are expected to serve as "attractors" for the time-dependent model. For example, the solutions of a diurnally forced model should remain close to the corresponding solutions of a diurnally averaged one. In this sense, steady-state models can provide an approximation to averaged conditions in the atmosphere. An exception occurs if the steady-state solution is unstable.

An unstable solution refers to a steady-state model in which the Jacobian matrix, evaluated at a solution, has at least one eigenvalue with a positive real part. The NewtonRaphson method used in solving the steady-state model (Stewart, 1993) uses the Jacobian, but not its eigenvalues. In a steady-state model there is thus no computational 
difference between stable and unstable solutions. If we now solve the same equations, but use a time-dependent method to study the behavior of the solutions near a steady state, the Jacobian eigenvalues appear as arguments of exponential functions that describe the model's temporal evolution. If the real parts of all eigenvalues are negative, the solution simply relaxes to the steady state, but any positive real part will drive the time-dependent solution away from the steady state. This is the meaning of instability and the consequence is that unstable steady-state solutions are inaccessible to a time-dependent model and cannot provide an approximation to conditions in the atmosphere.

Our interest in instability is in determining how a timedependent model behaves when underlying steady-state attractors, differing only by a small value of a parameter, are nonetheless widely separated in the state space of the system. This will occur in bistable regions referred to above. An example in the following is provided by steady states calculated on successive days of the year. The small change in solar zenith angle that this entails will, under some conditions, result in large changes in species concentrations. When these steady-state changes have a time-dependent analog we expect that, to the extent that the time-dependent model provides some approximation to the atmosphere, there may be observable consequences.

\section{Background}

\subsection{Tropospheric chemical regimes}

In both stratosphere and troposphere the source of ozone is molecular oxygen. In the stratosphere a single UV photon having wavelength $\lambda \leq 242 \mathrm{~nm}$ suffices to dissociate molecular oxygen and form $\mathrm{O}_{3}$ via reaction of the product $\mathrm{O}$ atoms with $\mathrm{O}_{2}$. Since these photons do not penetrate to the troposphere, ozone production utilizes two less energetic photons and a more involved sequence of chemical reactions. The first photon, $\lambda \leq 340 \mathrm{~nm}$, photolyzes a seed molecule of $\mathrm{O}_{3}$ yielding an excited-state oxygen atom, $\mathrm{O}\left({ }^{1} \mathrm{D}\right)$. This may then react with water vapor to form $\mathrm{OH}$. $\mathrm{OH}$ oxidation of a hydrocarbon (HC), represented by $\mathrm{CO}$ and $\mathrm{CH}_{4}$ in the following, releases $\mathrm{H}$ atoms or methyl radicals, respectively. These capture $\mathrm{O}_{2}$ to form $\mathrm{HO}_{2}$ or $\mathrm{CH}_{3} \mathrm{O}_{2}$ and, with sufficient $\mathrm{NO}$ present, an $\mathrm{O}$ atom is subsequently transferred to $\mathrm{NO}$ forming $\mathrm{NO}_{2}$. The second photon, $\lambda \leq 423 \mathrm{~nm}$, now photolyzes $\mathrm{NO}_{2}$ releasing $\mathrm{O}$ to form $\mathrm{O}_{3}$ as in the stratosphere. Since this process only consumes $\mathrm{HC}$ and $\mathrm{H}_{2} \mathrm{O}$ and not $\mathrm{NO}_{\mathrm{x}}$ or $\mathrm{HO}_{\mathrm{x}}$ there is no need for further $\mathrm{O}_{3}$ photolysis to continue $\mathrm{O}_{3}$ production. Ozone in the troposphere is thus its own precursor and its production is autocatalytic (Stewart, 1995). These ideas are elaborated in the remainder of this section.

A simplified photochemical scheme will be used to illustrate the behavior of the model used in this study. Such a simplification is often used to demonstrate basic properties of tropospheric chemistry and variants have appeared often in the literature (Tinsley and Field, 2001; Field et al., 2001; Kalachev and Field, 2001; Prather, 1994). The actual model chemistry is described later, but the simplified scheme will be a useful reference for interpreting model results and understanding conditions in which bifurcations in the steadystate model and low- $\mathrm{NO}_{\mathrm{x}}$, high- $\mathrm{NO}_{\mathrm{x}}$ transitions in the timedependent model occur. Many authors have discussed the reactions described below (e.g. Levy, 1971; Crutzen and Zimmermann, 1991; Kleinman, 1991; Lelieveld et al., 2002).

The photochemical system may be regarded as consisting of three sets described as follows: 1) Initiation, 2) Chain propagation, and 3) Termination.

\subsubsection{Initiation}

The initiation phase begins with the photolysis of an ozone molecule by solar UV radiation in the $300-340 \mathrm{~nm}$ range. This produces excited-state $\mathrm{O}\left({ }^{1} \mathrm{D}\right)$ atoms, some of which react with water vapor to form two $\mathrm{OH}$ radicals. These initial reactions may result in ozone loss or production, depending on subsequent reactions.

$\mathrm{O}_{3}+\mathrm{h} v \rightarrow \mathrm{O}\left({ }^{1} \mathrm{D}\right)+\mathrm{O}_{2}$

$\mathrm{O}\left({ }^{1} \mathrm{D}\right)+\mathrm{H}_{2} \mathrm{O} \rightarrow 2 \mathrm{OH}$

\subsubsection{Chain propagation}

The fate of oxidants after the initiation phase begins with oxidation of $\mathrm{CO}$. Carbon monoxide serves here as a surrogate for $\mathrm{CH}_{4}$ and other hydrocarbon species. Since $\mathrm{NO}_{\mathrm{x}}$ and $\mathrm{HO}_{\mathrm{x}}$ are not consumed in the following they are referred to collectively as chain propagation reactions.

$\mathrm{CO}+\mathrm{OH}+\mathrm{O}_{2} \rightarrow \mathrm{HO}_{2}+\mathrm{CO}_{2}$

$\mathrm{HO}_{2}+\mathrm{NO} \rightarrow \mathrm{NO}_{2}+\mathrm{OH}$

$\mathrm{HO}_{2}+\mathrm{O}_{3} \rightarrow \mathrm{OH}+2 \mathrm{O}_{2}$

$\mathrm{NO}_{2}+\mathrm{O}_{2}+\mathrm{h} v \rightarrow \mathrm{NO}+\mathrm{O}_{3}$

\subsubsection{Termination}

For simplicity only the following chain termination reactions are considered.

$$
\begin{aligned}
& \mathrm{OH}+\mathrm{NO}_{2}+\mathrm{M} \rightarrow \mathrm{HNO}_{3}+\mathrm{M} \\
& \mathrm{HO}_{2}+\mathrm{HO}_{2} \rightarrow \mathrm{H}_{2} \mathrm{O}_{2}+\mathrm{O}_{2}
\end{aligned}
$$

In a low- $\mathrm{NO}_{\mathrm{x}}$ regime the net chemistry may result in either ozone loss or production. If it results in production, large numbers of ozone molecules may be produced for each one initially photolyzed. Depending on the amount of $\mathrm{CO}$ or hydrocarbon (HC) available Reactions (3-5) may occur several times before a termination reaction occurs that removes radicals or $\mathrm{NO}_{\mathrm{x}}$ from the system. Suppose that Reactions (3-5) 
Table 1. Variable species included in the present model.

\begin{tabular}{lllc}
\hline No. & Species & Flux $\left(\mathrm{cm}^{-2} \mathrm{~s}^{-1}\right)$ & Dep. Velocity $(\mathrm{cm} / \mathrm{s})$ \\
\hline 1 & $\mathrm{O}_{3}$ & $7 \times 10^{10}$ & 0.4 \\
2 & $\mathrm{OH}$ & \\
3 & $\mathrm{HO}_{2}$ & & \\
4 & $\mathrm{H}_{2} \mathrm{O}_{2}$ & & 0.50 \\
5 & $\mathrm{NO}^{2}$ & variable & 0.016 \\
6 & $\mathrm{NO}_{2}$ & & 0.10 \\
7 & $\mathrm{HNO}_{3}$ & & 4.0 \\
8 & $\mathrm{CO}^{11}$ & 0.03 \\
9 & $\mathrm{CH}_{3} \mathrm{OOH}$ & & 0.1 \\
10 & $\mathrm{CH}_{3} \mathrm{O}_{2}$ & & \\
11 & $\mathrm{CH}_{2} \mathrm{OOH}$ & & 0.25 \\
12 & $\mathrm{H}_{2} \mathrm{CO}_{10}$ & \\
13 & $\mathrm{CH}_{3} \mathrm{OH}$ & & 0.1 \\
14 & $\mathrm{NO}_{3}$ & & 4.0 \\
15 & $\mathrm{~N}_{2} \mathrm{O}_{5}$ & & \\
16 & $\mathrm{HNO}_{2}$ & & \\
17 & $\mathrm{HNO}_{4}$ & & \\
18 & $\mathrm{C}_{2} \mathrm{H}_{4}$ & $2 \times 10^{9}$ & \\
19 & $\mathrm{C}_{2} \mathrm{H}_{4} \mathrm{OHO}$ & \\
20 & $\mathrm{C}_{2} \mathrm{H}_{4} \mathrm{OOH}$ & & \\
21 & $\mathrm{CH}_{2} \mathrm{O}_{2}$ & & \\
22 & $\mathrm{C}_{2} \mathrm{H}_{6}$ & $2 \times 10^{9}$ & \\
23 & $\mathrm{C}_{2} \mathrm{H}_{5} \mathrm{O}_{2}$ & & \\
24 & $\mathrm{CH}_{3} \mathrm{CHO}$ & & \\
25 & $\mathrm{CH}_{3} \mathrm{CO}$ & & \\
26 & $\mathrm{PAN}_{3}$ & & \\
\hline & & \\
\end{tabular}

occur $\mathrm{m}$ times before a termination reaction occurs. Further, within this sequence, suppose that Reaction (4a) occurs $m_{1}$ times and Reaction (4b) $m_{2}$ times with $m_{1}+m_{2}=m$. Then the net effect of Reactions (1-5) is:

\subsubsection{Net}

$\mathrm{O}_{3}+\mathrm{H}_{2} \mathrm{O}+\mathrm{mCO}+\left(2 \mathrm{~m}_{1}-\mathrm{m}_{2}-1\right) \mathrm{O}_{2} \rightarrow$

$\mathrm{mCO}_{2}+2 \mathrm{OH}+\left(\mathrm{m}_{1}-\mathrm{m}_{2}\right) \mathrm{O}_{3}$

The above system behaves in the following way.

Net Production of $\mathrm{O}_{3}: \mathrm{m}_{1}>\mathrm{m}_{2}+1$

$\mathrm{O}_{3}$ neutral: $\mathrm{m}_{1}=\mathrm{m}_{2}+1$

Net destruction of $\mathrm{O}_{3}: \mathrm{m}_{1}<\mathrm{m}_{2}+1$

The transition from ozone destruction to ozone production in the low- $\mathrm{NO}_{\mathrm{x}}$ regime occurs when the reaction rates $(4 \mathrm{a})$ and $(4 \mathrm{~b})$ are approximately equal, i.e. $\mathrm{k}_{4 b}\left[\mathrm{O}_{3}\right] \approx \mathrm{k}_{4 a}[\mathrm{NO}]$.

Once there is sufficient NO in the system to provide net chemical production, we see from the net reaction that this production is autocatalytic with $\mathrm{m}_{1}-\mathrm{m}_{2}$ ozone molecules produced for each one destroyed. For $\mathrm{CH}_{4}$ or NMHC con- sumption, the potential ozone production is greater, but details will not be considered here.

Dominance of Reaction (4b) over (4a), if it occurs, does not imply that $\mathrm{HO}_{2}+\mathrm{O}_{3}$ is itself a major ozone loss mechanism. The competition between $\mathrm{O}_{3}$ and $\mathrm{NO}$ for $\mathrm{HO}_{2}$ simply provides a switch that, if $\mathrm{O}_{3}$ is favored, allows ozone photolysis to act as the principal ozone loss mechanism rather than as the first step in the autocatalytic production of ozone. This process was described as inhibition (of ozone production) in Stewart (1995).

The effects of these reactions are summarized in Fig. 1. The circles represent species playing the role of sources $(\mathrm{HC})$ or sinks $\left(\mathrm{H}_{2} \mathrm{O}_{2}\right.$ and $\left.\mathrm{HNO}_{3}\right)$ for the more reactive species shown in the boxes. In this figure, the light-blue boxes and circles and dark-blue arrows indicate the chemistry of the low- $\mathrm{NO}_{\mathrm{x}}$, ozone loss regime. $\mathrm{OH}$ production through $\mathrm{Re}-$ actions (1) and (2) is followed by conversion to $\mathrm{HO}_{2}$ via hydrocarbon oxidation and then loss of $\mathrm{HO}_{\mathrm{x}}$ and $\mathrm{O}_{3}$ after Reaction (7) forms peroxide. The path Reaction (3) followed by Reaction (7) shows the loss of ozone and odd hydrogen. Net production of oxidants does not occur in this system.

Adding $\mathrm{NO}_{\mathrm{x}}$ to the system provides the mechanism for autocatalytic production of ozone. This is shown by adding the brown boxes and green arrows in Fig. 1. The dotted green arrows in the diagram show the recycling of $\mathrm{NO}_{\mathrm{x}}$ and $\mathrm{HO}_{\mathrm{x}}$. The arrows connected to small filled circles in the $\mathrm{HO}_{2}$ box indicate the alternate pathways that may be followed by $\mathrm{HO}_{2}$. The low- $\mathrm{NO}_{\mathrm{x}}$ switch from ozone loss to production occurs when the Reaction (4a) path dominates Reaction (4b) as described above.

Finally, when enough $\mathrm{NO}_{\mathrm{x}}$ is present, $\mathrm{OH}$ will react preferentially with $\mathrm{NO}_{2}$ to form nitric acid. This establishes the high- $\mathrm{NO}_{\mathrm{x}}$ regime shown by adding the red circle $\left(\mathrm{HNO}_{3}\right)$ and arrows on the left side of Fig. 1. Once this occurs the low- $\mathrm{NO}_{\mathrm{x}}$ paths on the right of the figure are substantially shut down and production of oxidants, including $\mathrm{H}_{2} \mathrm{O}_{2}$, becomes negligible. The small filled circles in the $\mathrm{OH}$ box indicate the switch between low and high- $\mathrm{NO}_{\mathrm{x}}$ chemistry.

\subsection{Model description}

\subsubsection{Methods and Parameters}

Many model details are the same as described in Stewart (1993, 1995). A box model (Stewart, et al., 1983) is used to compute species concentrations. A Newton-Raphson method (Press et al., 1992), modified to enhance its robustness (Stewart, 1993), is used to compute steady-state solutions and the LSODE integrator (Hindmarsh, 1983) is used for timedependent runs. Methane is held fixed at a mixing ratio of $1.7 \mathrm{ppm}$. Temperature is assumed to vary through the year from $273 \mathrm{~K}$ to $297 \mathrm{~K}$ similar to the model of Kleinman (1991). Water vapor varies with an annual cycle consistent with the temperature change and the assumption of a fixed $60 \%$ relative humidity. Fixed ozone burdens of 300 D.U. and 


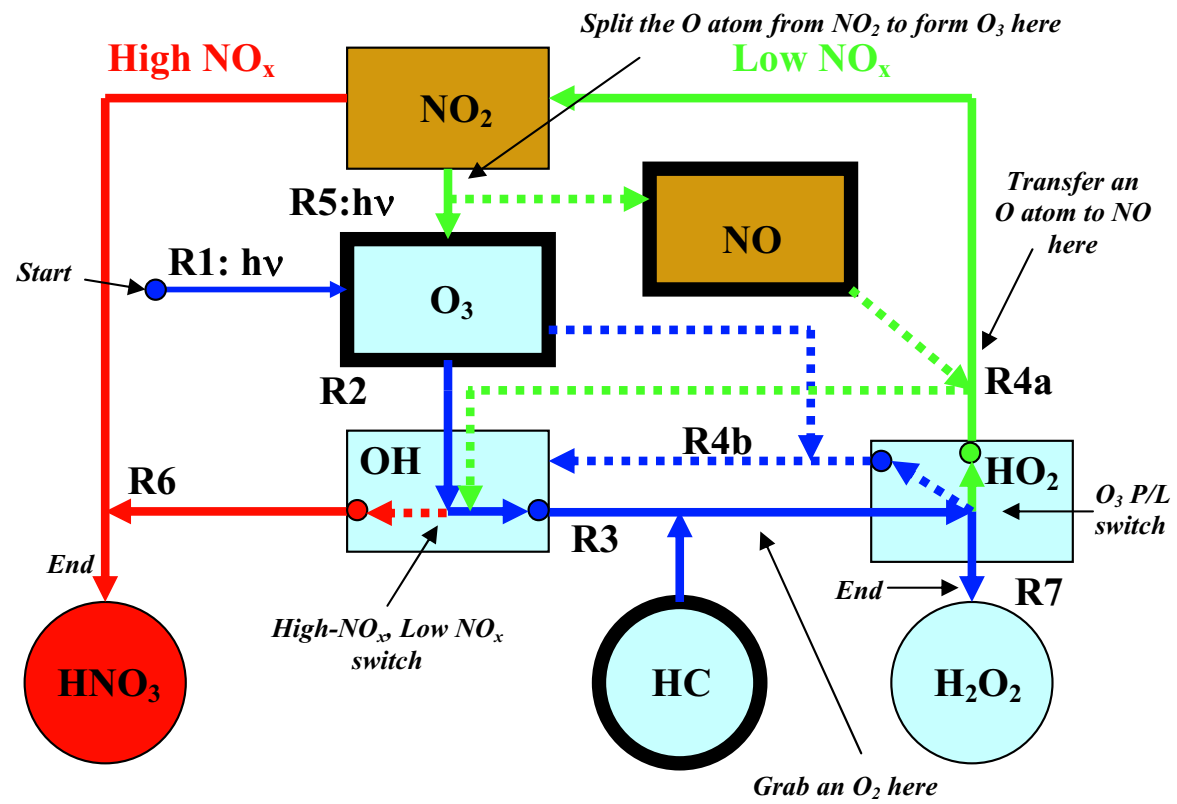

Fig. 1. Diagram illustrating the effects of the basic Reactions (1-7). Boxes bounded by thick lines indicate species having physical sources. The differently colored boxes and arrows indicate Low- $\mathrm{NO}_{\mathrm{x}}$ ozone loss (blue), low- $\mathrm{NO}_{\mathrm{x}}$ ozone production (blue and brown) and high- $\mathrm{NO}_{\mathrm{x}}$ (red) regimes.

boundary layer height of $1 \mathrm{~km}$. have been used in the results reported below. Test calculations have been made with annual variations of these last parameters, but without significant change in the results.

There are 26 variable species (Table 1) undergoing 65 reactions (Table 2). In addition to their chemical interactions, several species shown in Table 1 are assumed to have physical sources and/or sinks. The physical source of $\mathrm{O}_{3}$ is transport from the stratosphere. The mean value used for the $\mathrm{O}_{3}$ flux is in the range discussed by Holton and Lelieveld (1994). The CO source is based on a global anthropogenic source value (Olivier et al., 1999). Sources for ethene and ethane are assumed that give values of these species consistent with observations (Bottenheim and Shepherd, 1995) over some range of model runs. Except for $\mathrm{H}_{2} \mathrm{CO}$, deposition velocities are from the model study of Hauglustaine et al. (1994). The formaldehyde deposition rate is assumed the same as that for $\mathrm{CH}_{3} \mathrm{CHO}$. In all cases fluxes and deposition velocities are converted to sources and loss coefficients by dividing by the boundary layer height of $1 \mathrm{~km}$. No other exchange processes, such as coupling to a specified ambient atmosphere, are considered in this model.

Some experimentation has been carried out with all of these model parameters. The main qualitative features discussed below, namely the existence of spring and fall transitions between high and low- $\mathrm{NO}_{\mathrm{x}}$ regimes in both steadystate and time-dependent models, have not been sensitive to the values used.

\subsubsection{Chemistry}

Table 2 presents the chemical reactions used in this study. Photolysis rates are computed from the Madronich (1987) model for clear sky conditions at $40^{\circ} \mathrm{N}$. Reaction rates are mostly taken from Demore et al. (1997) and Atkinson et al. (1992). A few tests were made with updated values given in the compilation of Sander et al. (2003) with no significant change in results. Some of the reactions in Table 2 have products that react with $\mathrm{O}_{2}$. In such cases, the products shown are those subsequent to the $\mathrm{O}_{2}$ reaction. Reaction (1) showing ozone yielding $\mathrm{OH}$ directly is a composite reaction having an effective rate coefficient that depends on water vapor concentration as well as total number density. The effective rate is similar to that discussed in Stewart (1995), but is now treated as a photolysis rate rather than a bimolecular rate involving $\mathrm{H}_{2} \mathrm{O}$. Hydrolysis of $\mathrm{N}_{2} \mathrm{O}_{5}$ (Reaction 41 in Table 2) follows the discussion of Dimitroulopoulou and Marsh (1997) using an effective rate that accounts for both heterogeneous and homogeneous reactions. Reactions (50) and (51) following the oxidation of $\mathrm{C}_{2} \mathrm{H}_{4}$ by $\mathrm{OH}$ (Reaction 49) are based on the oxidation sequence given in Barker (1995). The rate for Reaction (50) is a guess taken to be of a magnitude similar to the rates for $\mathrm{HO}_{2}+\mathrm{NO}$ and $\mathrm{CH}_{3} \mathrm{O}_{2}+\mathrm{NO}$. The thermolysis rate for Reaction (51) is also a guess taken to be the same as the rate for $\mathrm{HNO}_{4}$ thermolysis. The Reactions (52) and (53) are based on Barker (1995) as well as the discussion of Paulson (1995). 
Table 2. Reactions used in the current model. The temperature used for rate evaluation is $278 \mathrm{~K}$. This is the temperature at noon on 1 January in the model. Rate numbers in parentheses correspond to the numbers in Sect. 2.1

\begin{tabular}{|c|c|c|}
\hline No. & Name & $\operatorname{Rate}\left(\mathrm{cm}^{3} \mathrm{~s}^{-1}\right)$ \\
\hline $\mathrm{R} 1(\mathrm{R} 1+\mathrm{R} 2)$ & $\mathrm{O}_{3}+\mathrm{h} v \rightarrow 2 \mathrm{OH}$ & $2.03 \mathrm{D}-07$ \\
\hline R2 (R5) & $\mathrm{NO}_{2}+\mathrm{h} \nu \rightarrow \mathrm{NO}+\mathrm{O}_{3}$ & $6.42 \mathrm{D}-03$ \\
\hline R3 & $\mathrm{H}_{2} \mathrm{O}_{2}+\mathrm{h} v \rightarrow \mathrm{OH}+\mathrm{OH}$ & $3.45 \mathrm{D}-06$ \\
\hline R4 & $\mathrm{HNO}_{3}+\mathrm{h} v \rightarrow \mathrm{OH}+\mathrm{NO}_{2}$ & $1.97 \mathrm{D}-07$ \\
\hline R5 & $\mathrm{PAN}+\mathrm{h} v \rightarrow \mathrm{CH}_{3} \mathrm{CO}_{3}+\mathrm{NO}_{2}$ & 2.10D-07 \\
\hline R6 & $\mathrm{OH}+\mathrm{HO}_{2} \rightarrow \mathrm{H}_{2} \mathrm{O}+\mathrm{O}_{2}$ & $1.18 \mathrm{D}-10$ \\
\hline R7 & $\mathrm{H}_{2} \mathrm{O}_{2}+\mathrm{OH} \rightarrow \mathrm{HO}_{2}+\mathrm{H}_{2} \mathrm{O}$ & $1.63 \mathrm{D}-12$ \\
\hline $\mathrm{R} 8$ & $\mathrm{OH}+\mathrm{O}_{3} \rightarrow \mathrm{HO}_{2}+\mathrm{O}_{2}$ & $5.45 \mathrm{D}-14$ \\
\hline R9 (R4b) & $\mathrm{HO}_{2}+\mathrm{O}_{3} \rightarrow \mathrm{OH}+2 \mathrm{O}_{2}$ & $1.82 \mathrm{D}-15$ \\
\hline $\mathrm{R} 10$ (R4a) & $\mathrm{NO}+\mathrm{HO}_{2} \rightarrow \mathrm{OH}+\mathrm{NO}_{2}$ & 8.60D-12 \\
\hline $\mathrm{R} 11$ & $\mathrm{NO}+\mathrm{O}_{3} \rightarrow \mathrm{NO}_{2}+\mathrm{O}_{2}$ & 1.30D-14 \\
\hline R12 (R3) & $\mathrm{CO}+\mathrm{OH} \rightarrow \mathrm{CO}_{2}+\mathrm{HO}_{2}$ & $2.44 \mathrm{D}-13$ \\
\hline $\mathrm{R} 13$ & $\mathrm{OH}+\mathrm{OH}+\mathrm{M} \rightarrow \mathrm{H}_{2} \mathrm{O}_{2}+\mathrm{M}$ & $6.15 \mathrm{D}-12$ \\
\hline R14 (R6) & $\mathrm{OH}+\mathrm{NO}_{2}+\mathrm{M} \rightarrow \mathrm{HNO}_{3}+\mathrm{M}$ & $1.05 \mathrm{D}-11$ \\
\hline R15 (R7) & $\mathrm{HO}_{2}+\mathrm{HO}_{2}+\mathrm{M} \rightarrow \mathrm{H}_{2} \mathrm{O}_{2}+\mathrm{O}_{2}+\mathrm{M}$ & 5.33D-12 \\
\hline R16 & $\mathrm{H}_{2} \mathrm{CO}+\mathrm{h} v \rightarrow 2 \mathrm{HO}_{2}+\mathrm{CO}$ & $1.66 \mathrm{D}-05$ \\
\hline R17 & $\mathrm{H}_{2} \mathrm{CO}+\mathrm{h} v \rightarrow \mathrm{CO}+\mathrm{H}_{2}$ & $2.80 \mathrm{D}-05$ \\
\hline R18 & $\mathrm{CH}_{3} \mathrm{OOH}+\mathrm{h} v \rightarrow \mathrm{CH}_{3} \mathrm{O}_{2}+\mathrm{OH}$ & 3.10D-06 \\
\hline R19 & $\mathrm{CH}_{4}+\mathrm{OH} \rightarrow \mathrm{CH}_{3} \mathrm{O}_{2}+\mathrm{H}_{2} \mathrm{O}$ & 4.15D-15 \\
\hline $\mathrm{R} 20$ & $\mathrm{CH}_{3} \mathrm{O}_{2}+\mathrm{HO}_{2} \rightarrow \mathrm{CH}_{3} \mathrm{OOH}+\mathrm{O}_{2}$ & 6.74D-12 \\
\hline $\mathrm{R} 21$ & $\mathrm{CH}_{3} \mathrm{OOH}+\mathrm{OH} \rightarrow \mathrm{CH}_{3} \mathrm{O}_{2}+\mathrm{H}_{2} \mathrm{O}$ & $5.46 \mathrm{D}-12$ \\
\hline $\mathrm{R} 22$ & $\mathrm{CH}_{3} \mathrm{OOH}+\mathrm{OH} \rightarrow \mathrm{CH}_{2} \mathrm{OOH}+\mathrm{H}_{2} \mathrm{O}$ & 2.30D-12 \\
\hline $\mathrm{R} 23$ & $\mathrm{CH}_{2} \mathrm{OOH}+\mathrm{M} \rightarrow \mathrm{H}_{2} \mathrm{CO}+\mathrm{OH}$ & $1.00 \mathrm{D}-12$ \\
\hline $\mathrm{R} 24$ & $\mathrm{CH}_{3} \mathrm{O}_{2}+\mathrm{CH}_{3} \mathrm{O}_{2} \rightarrow 2 \mathrm{H}_{2} \mathrm{CO}+2 \mathrm{HO}_{2}$ & $1.95 \mathrm{D}-13$ \\
\hline $\mathrm{R} 25$ & $\mathrm{CH}_{3} \mathrm{O}_{2}+\mathrm{CH}_{3} \mathrm{O}_{2} \rightarrow \mathrm{H}_{2} \mathrm{CO}+\mathrm{CH}_{3} \mathrm{OH}+\mathrm{O}_{2}$ & $2.92 \mathrm{D}-13$ \\
\hline $\mathrm{R} 26$ & $\mathrm{CH}_{3} \mathrm{OH}+\mathrm{OH} \rightarrow \mathrm{H}_{2} \mathrm{O}+\mathrm{CH}_{3} \mathrm{O}_{2}$ & $8.15 \mathrm{D}-13$ \\
\hline $\mathrm{R} 27$ & $\mathrm{NO}+\mathrm{CH}_{3} \mathrm{O}_{2} \rightarrow \mathrm{NO}_{2}+\mathrm{H}_{2} \mathrm{CO}+\mathrm{HO}_{2}$ & 8.21D-12 \\
\hline $\mathrm{R} 28$ & $\mathrm{H}_{2} \mathrm{CO}+\mathrm{OH} \rightarrow \mathrm{CO}+\mathrm{HO}_{2}$ & $1.00 \mathrm{D}-11$ \\
\hline $\mathrm{R} 29$ & $\mathrm{NO}_{3}+\mathrm{h} v \rightarrow \mathrm{NO}_{2}+\mathrm{O}_{3}$ & $1.56 \mathrm{D}-01$ \\
\hline R30 & $\mathrm{NO}_{3}+\mathrm{h} \nu \rightarrow \mathrm{NO}+\mathrm{O}_{2}$ & $2.04 \mathrm{D}-02$ \\
\hline R31 & $\mathrm{N}_{2} \mathrm{O}_{5}+\mathrm{h} v \rightarrow \mathrm{NO}_{2}+\mathrm{NO}_{3}$ & $1.23 \mathrm{D}-05$ \\
\hline R32 & $\mathrm{HNO}_{3}+\mathrm{OH} \rightarrow \mathrm{NO}_{3}+\mathrm{H}_{2} \mathrm{O}$ & $1.96 \mathrm{D}-13$ \\
\hline R33 & $\mathrm{NO}_{2}+\mathrm{O}_{3} \rightarrow \mathrm{NO}_{3}+\mathrm{O}_{2}$ & $1.80 \mathrm{D}-17$ \\
\hline R34 & $\mathrm{NO}_{3}+\mathrm{NO}_{2} \rightarrow \mathrm{NO}+\mathrm{NO}_{2}+\mathrm{O}_{2}$ & 5.39D-16 \\
\hline R35 & $\mathrm{NO}_{3}+\mathrm{NO} \rightarrow 2 \mathrm{NO}_{2}$ & $2.76 \mathrm{D}-11$ \\
\hline R36 & $\mathrm{NO}_{3}+\mathrm{NO}_{3} \rightarrow 2 \mathrm{NO}_{2}+\mathrm{O}_{2}$ & $1.56 \mathrm{D}-16$ \\
\hline
\end{tabular}

\section{Results}

\subsection{The computed annual cycle of $\mathrm{H}_{2} \mathrm{O}_{2}$}

The primary control parameter in this study is the day of the year. Steady-state concentrations for the variable species given in Table 1 are computed on successive days throughout the year using noon photolysis rates multiplied by the daylight fraction. This implies a corresponding small variation in solar zenith angle between runs and it is also reasonable to consider zenith angle as the primary control parameter. The secondary control parameter is the nitric oxide source, $\mathrm{S}_{\mathrm{NO}}$. A range of source fluxes from $4 \times 10^{9}$ to $4 \times 10^{12} \mathrm{~cm}^{-2} \mathrm{~s}^{-1}$
Table 2. Continued.

\begin{tabular}{|c|c|c|}
\hline R37 & $\mathrm{OH}+\mathrm{NO}_{3} \rightarrow \mathrm{HO}_{2}+\mathrm{NO}_{2}$ & $2.30 \mathrm{D}-11$ \\
\hline R38 & $\mathrm{HO}_{2}+\mathrm{NO}_{3} \rightarrow \mathrm{HNO}_{3}+\mathrm{O}_{2}$ & $2.05 \mathrm{D}-12$ \\
\hline R39 & $\mathrm{HO}_{2}+\mathrm{NO}_{3} \rightarrow \mathrm{OH}+\mathrm{NO}_{2}+\mathrm{O}_{2}$ & $3.55 \mathrm{D}-12$ \\
\hline $\mathrm{R} 40$ & $\mathrm{NO}_{3}+\mathrm{H}_{2} \mathrm{CO} \rightarrow \mathrm{HNO}_{3}+\mathrm{HO}_{2}+\mathrm{CO}$ & 4.32D-16 \\
\hline $\mathrm{R} 41$ & $\mathrm{~N}_{2} \mathrm{O}_{5}+\mathrm{H}_{2} \mathrm{O} \rightarrow \mathrm{HNO}_{3}+\mathrm{HNO}_{3}$ & $9.85 \mathrm{D}-22$ \\
\hline $\mathrm{R} 42$ & $\mathrm{NO}_{3}+\mathrm{NO}_{2}+\mathrm{M} \rightarrow \mathrm{N}_{2} \mathrm{O}_{5}+\mathrm{M}$ & $1.35 \mathrm{D}-12$ \\
\hline $\mathrm{R} 43$ & $\mathrm{~N}_{2} \mathrm{O}_{5} \rightarrow \mathrm{NO}_{3}+\mathrm{NO}_{2}$ & 3.97D-03 \\
\hline $\mathrm{R} 44$ & $\mathrm{HNO}_{2}+\mathrm{h} v \rightarrow \mathrm{OH}+\mathrm{NO}$ & 2.50D-03 \\
\hline $\mathrm{R} 45$ & $\mathrm{HNO}_{4}+\mathrm{h} v \rightarrow \mathrm{HO}_{2}+\mathrm{NO}_{2}$ & $2.03 \mathrm{D}-06$ \\
\hline $\mathrm{R} 46$ & $\mathrm{NO}_{2}+\mathrm{HO}_{2}+\mathrm{M} \rightarrow \mathrm{HNO}_{4}+\mathrm{M}$ & $1.62 \mathrm{D}-12$ \\
\hline $\mathrm{R} 47$ & $\mathrm{OH}+\mathrm{NO}+\mathrm{M} \rightarrow \mathrm{HNO}_{2}+\mathrm{M}$ & 7.90D-12 \\
\hline $\mathrm{R} 48$ & $\mathrm{HNO}_{4} \rightarrow \mathrm{HO}_{2}+\mathrm{NO}_{2}$ & $8.21 \mathrm{D}-03$ \\
\hline $\mathrm{R} 49$ & $\mathrm{C}_{2} \mathrm{H}_{4}+\mathrm{OH}+\mathrm{M} \rightarrow \mathrm{C}_{2} \mathrm{H}_{4} \mathrm{OHO}_{2}$ & $8.16 \mathrm{D}-12$ \\
\hline R50 & $\mathrm{C}_{2} \mathrm{H}_{4} \mathrm{OHO}_{2}+\mathrm{NO} \rightarrow \mathrm{C}_{2} \mathrm{H}_{4} \mathrm{OOH}+\mathrm{NO}_{2}$ & $2.00 \mathrm{D}-12$ \\
\hline R51 & $\mathrm{C}_{2} \mathrm{H}_{4} \mathrm{OOH}+\mathrm{M} \rightarrow 2 \mathrm{H}_{2} \mathrm{CO}+\mathrm{HO}_{2}$ & $1.96 \mathrm{D}-02$ \\
\hline R52 & $\mathrm{C}_{2} \mathrm{H}_{4}+\mathrm{O}_{3} \rightarrow \mathrm{H}_{2} \mathrm{CO}+\mathrm{CH}_{2} \mathrm{O}_{2}$ & $5.85 \mathrm{D}-19$ \\
\hline R53 & $\mathrm{C}_{2} \mathrm{H}_{4}+\mathrm{O}_{3} \rightarrow \mathrm{H}_{2} \mathrm{CO}+\mathrm{HO}_{2}+\mathrm{OH}$ & $5.85 \mathrm{D}-19$ \\
\hline R54 & $\mathrm{CH}_{2} \mathrm{O}_{2}+\mathrm{HO}_{2} \rightarrow \mathrm{H}_{2} \mathrm{CO}+\mathrm{OH}$ & $1.00 \mathrm{D}-11$ \\
\hline R55 & $\mathrm{C}_{2} \mathrm{H}_{6}+\mathrm{OH} \rightarrow \mathrm{C}_{2} \mathrm{H}_{5} \mathrm{O}_{2}+\mathrm{H}_{2} \mathrm{O}$ & $1.86 \mathrm{D}-13$ \\
\hline R56 & $\mathrm{C}_{2} \mathrm{H}_{5} \mathrm{O}_{2}+\mathrm{NO} \rightarrow \mathrm{NO}_{2}+\mathrm{HO}_{2}+\mathrm{CH}_{3} \mathrm{CHO}$ & $9.66 \mathrm{D}-12$ \\
\hline R57 & $\mathrm{CH}_{3} \mathrm{CHO}+\mathrm{h} \nu \rightarrow \mathrm{CH}_{3} \mathrm{O}_{2}+\mathrm{HO}_{2}+\mathrm{CO}$ & $2.21 \mathrm{D}-06$ \\
\hline R58 & $\mathrm{CH}_{3} \mathrm{CHO}+\mathrm{h} \nu \rightarrow \mathrm{CH}_{3} \mathrm{CO}_{3}+\mathrm{HO}_{2}$ & 9.71D-07 \\
\hline R59 & $\mathrm{CH}_{3} \mathrm{CHO}+\mathrm{OH} \rightarrow \mathrm{CH}_{3} \mathrm{CO}_{3}+\mathrm{H}_{2} \mathrm{O}$ & $1.48 \mathrm{D}-11$ \\
\hline R60 & $\mathrm{CH}_{3} \mathrm{CHO}+\mathrm{NO}_{3} \rightarrow \mathrm{CH}_{3} \mathrm{CO}_{3}+\mathrm{HNO}_{3}$ & $1.77 \mathrm{D}-15$ \\
\hline R61 & $\mathrm{CH}_{3} \mathrm{CO}_{3}+\mathrm{NO}_{2} \rightarrow$ PAN & $9.70 \mathrm{D}-12$ \\
\hline R62 & $\mathrm{PAN} \rightarrow \mathrm{CH}_{3} \mathrm{CO}_{3}+\mathrm{NO}_{2}$ & $2.05 \mathrm{D}-05$ \\
\hline R63 & $\mathrm{CH}_{3} \mathrm{CO}_{3}+\mathrm{HO}_{2} \rightarrow \mathrm{M}$ & $1.51 \mathrm{D}-11$ \\
\hline R64 & $\mathrm{CH}_{3} \mathrm{CO}_{3}+\mathrm{CH}_{3} \mathrm{CO}_{3} \rightarrow 2 \mathrm{CH}_{3} \mathrm{O}_{2}$ & $1.75 \mathrm{D}-11$ \\
\hline R65 & $\mathrm{CH}_{3} \mathrm{CO}_{3}+\mathrm{NO} \rightarrow \mathrm{NO}_{2}+\mathrm{CH}_{3} \mathrm{O}_{2}$ & $1.93 \mathrm{D}-11$ \\
\hline
\end{tabular}

has been used in the calculations. A time-dependent model has been run for a two-year period with annual and diurnal forcing for several of the $\mathrm{S}_{\mathrm{NO}}$ values used in the steady-state model. The annual cycles of $\mathrm{H}_{2} \mathrm{O}_{2}$ from the steady-state model and from the second year of the time-dependent model are compared in this section.

In panels (c) and (d) of the following Figs. 2-5, the displayed rates of $\mathrm{OH}$ and $\mathrm{HO}_{2}$ reaction are keyed to the discussion in section 2.1 and the mechanism shown in Fig. 1. In some cases, at the higher $\mathrm{NO}_{\mathrm{x}}$ levels, the formation of nitrous or pernitric acid is actually among the top three rates. Rapid photolysis or thermolysis however will make these "do nothing" reactions and their exclusion is justified. In the models displayed in the following figures, reaction of $\mathrm{OH}$ with $\mathrm{NMHC}$ is not competitive with the rates shown.

Figure 2 shows steady-state calculations (a), the corresponding time-dependent results (b), the time-dependent variation of noon values of $\mathrm{OH}$ loss due to reaction with $\mathrm{CO}$ and $\mathrm{CH}_{4}$ and with $\mathrm{NO}_{2}$ throughout the year (c), and the $\mathrm{HO}_{2}$ loss due to reactions with $\mathrm{NO}$ and $\mathrm{O}_{3}$ along with the $\mathrm{H}_{2} \mathrm{O}_{2}$ production rate $(\mathrm{d})$. The $\mathrm{NO}$ source value in these calculations is the lowest considered and results in a $\mathrm{NO}_{\mathrm{x}}$ background that ranges from about 40 to 80 ppt. A regional 

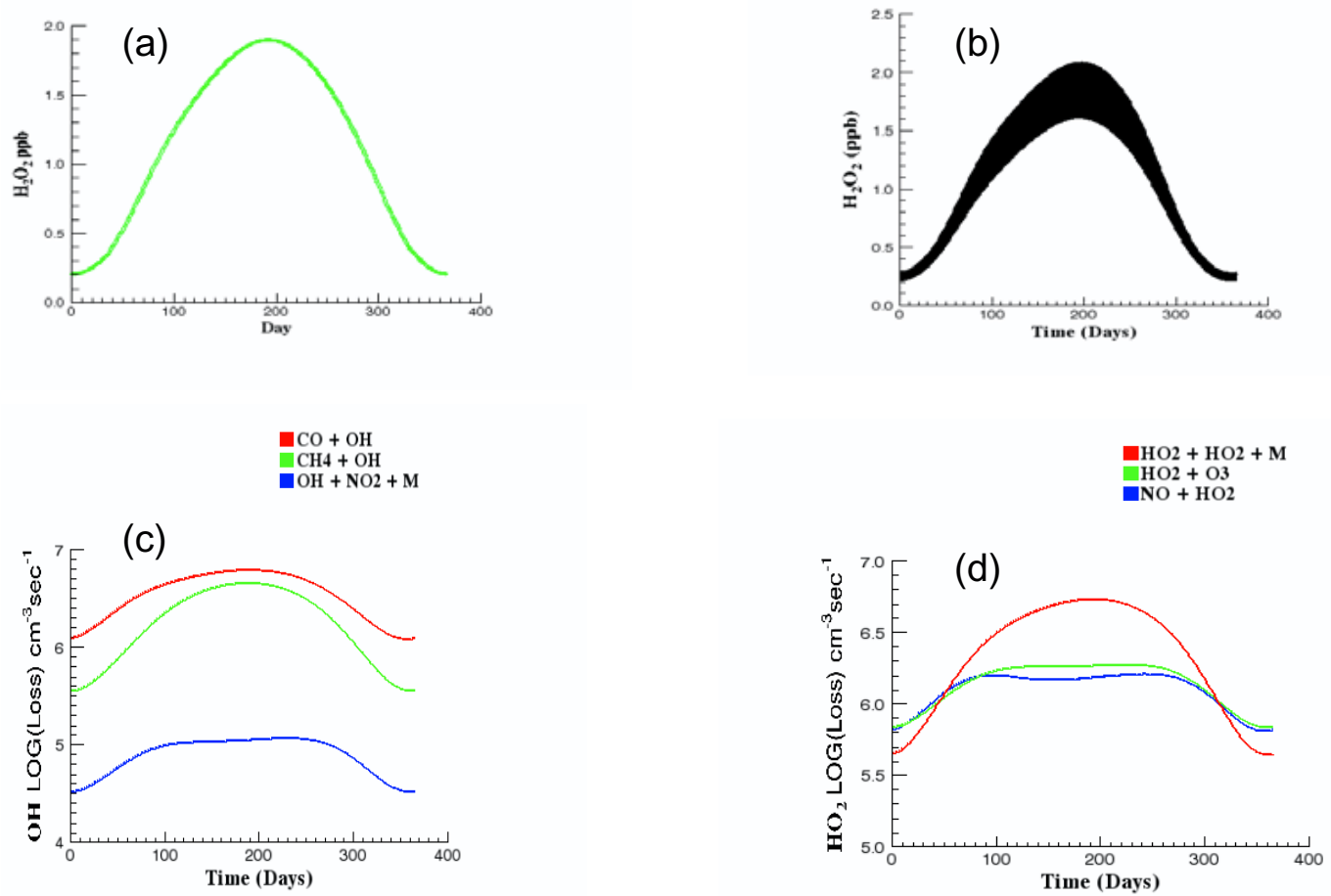

Fig. 2. Steady-state (a) and time-dependent (b), (c) and (d) calculations for the lowest $\mathrm{S}_{\mathrm{NO}}$ considered. The NO source here is $4 \times 10^{4} \mathrm{~cm}^{-3} \mathrm{~s}^{-1}$ and results in a summer to winter range of background $\mathrm{NO}_{\mathrm{x}}$ of 40 to 80 ppt. Low $\mathrm{NO}_{\mathrm{x}}$ conditions prevail throughout the year as shown by the dominance of $\mathrm{CO}$ (red) and $\mathrm{CH}_{4}$ (green) oxidation over $\mathrm{HNO}_{3}$ formation (blue) in panel (c). Panel (d) indicates that the net chemistry is ozone destroying throughout the year. The color scheme in parts (c) and (d) is based on the integrated loss by a reaction over an annual cycle, not on the reaction name. In some of the following figures the reactions will be represented by different colors.

characterization based on this range would be remote tropical forest (National Research Council, 1992). This, and similar $\mathrm{NRC}$ characterizations noted later, refers only to $\mathrm{NO}_{\mathrm{x}}$ levels and not to other aspects of the chemistry. Smaller $\mathrm{NO}_{\mathrm{x}}$ sources would result in an annual low- $\mathrm{NO}_{\mathrm{x}}$ cycle characteristic of the remote marine troposphere. Both steady-state and time-dependent $\mathrm{H}_{2} \mathrm{O}_{2}$ mixing ratios vary from a winter low of about $.25 \mathrm{ppb}$ to a summer high of about $2 \mathrm{ppb}$. The annual cycle of $\mathrm{H}_{2} \mathrm{O}_{2}$ shown in Fig. $2 \mathrm{~b}$ is qualitatively similar to the observations of Ayers et al. (1996), but with a higher summer maximum as would be expected for higher $\left[\mathrm{NO}_{\mathrm{x}}\right]$ mixing ratio. Figure $2 \mathrm{c}$ indicates that low $\mathrm{NO}_{\mathrm{x}}$ conditions prevail throughout the year in this model since nitric acid formation is never competitive with hydrocarbon oxidation. A similar comparison of $\mathrm{HO}_{2}$ loss rates (d) shows that the chemistry results in net ozone destruction throughout most of the year. In this model ozone photolysis removes odd oxygen and peroxide formation removes odd hydrogen.

The effect of increasing $\mathrm{S}_{\mathrm{NO}}$ from that used in this model is to depress the winter mixing ratio and increase the summer high. The chemistry remains low- $\mathrm{NO}_{\mathrm{x}}$ throughout the year until, at $\mathrm{S}_{\mathrm{NO}} \approx 3.7 \times 10^{5} \mathrm{~cm}^{-3} \mathrm{~s}^{-1}$, a narrow region of bistability first appears that spans a single day, 8 February in late winter and 25 November in fall. Further increases in $\mathrm{S}_{\mathrm{NO}}$ in- crease the bistable ranges and move their locations towards spring and early fall.

Figure 3 shows the same series of calculations as Fig. 2 with an NO source of $2 \times 10^{6} \mathrm{~cm}^{-3} \mathrm{~s}^{-1}$. This $S_{\mathrm{NO}}$ value was chosen because it is in a range characteristic of the northeastern US and is similar to values used by Kleinman (1991) and Jacob et al. (1995). The range of background $\mathrm{NO}_{\mathrm{x}}$ mixing ratios in this calculation is 0.5 to $5 \mathrm{ppb}$, which may be classified as a rural environment (National Research Council, 1992). In this figure, and those following, the $\mathrm{H}_{2} \mathrm{O}_{2}$ units in the steady-state calculation, part (a), will be shown as $\log _{10}$ concentration rather than mixing ratio, as in Fig. 2a, to show the full range of summer to winter variation. Mixing ratios will be retained for the time-dependent profile, Fig. 3b, since this will better exhibit the transitions of interest. The $\mathrm{H}_{2} \mathrm{O}_{2}$ detection limit depends on measurement method, but is of the order of several to several tens of ppt (Lee et al., 2000). Mixing ratios along the abscissa in Fig. $3 \mathrm{~b}$ and subsequent figures may be regarded as unobservable.

The steady-state profile, Fig. 3a, now exhibits a mushroom shape (Grey and Scott, 1990). In this model the mushroom results from the symmetry of the spring/fall calculation and consists of two conjoined hysteresis curves. The bistable regions extend from days 78 to 91 in the spring (19 March 

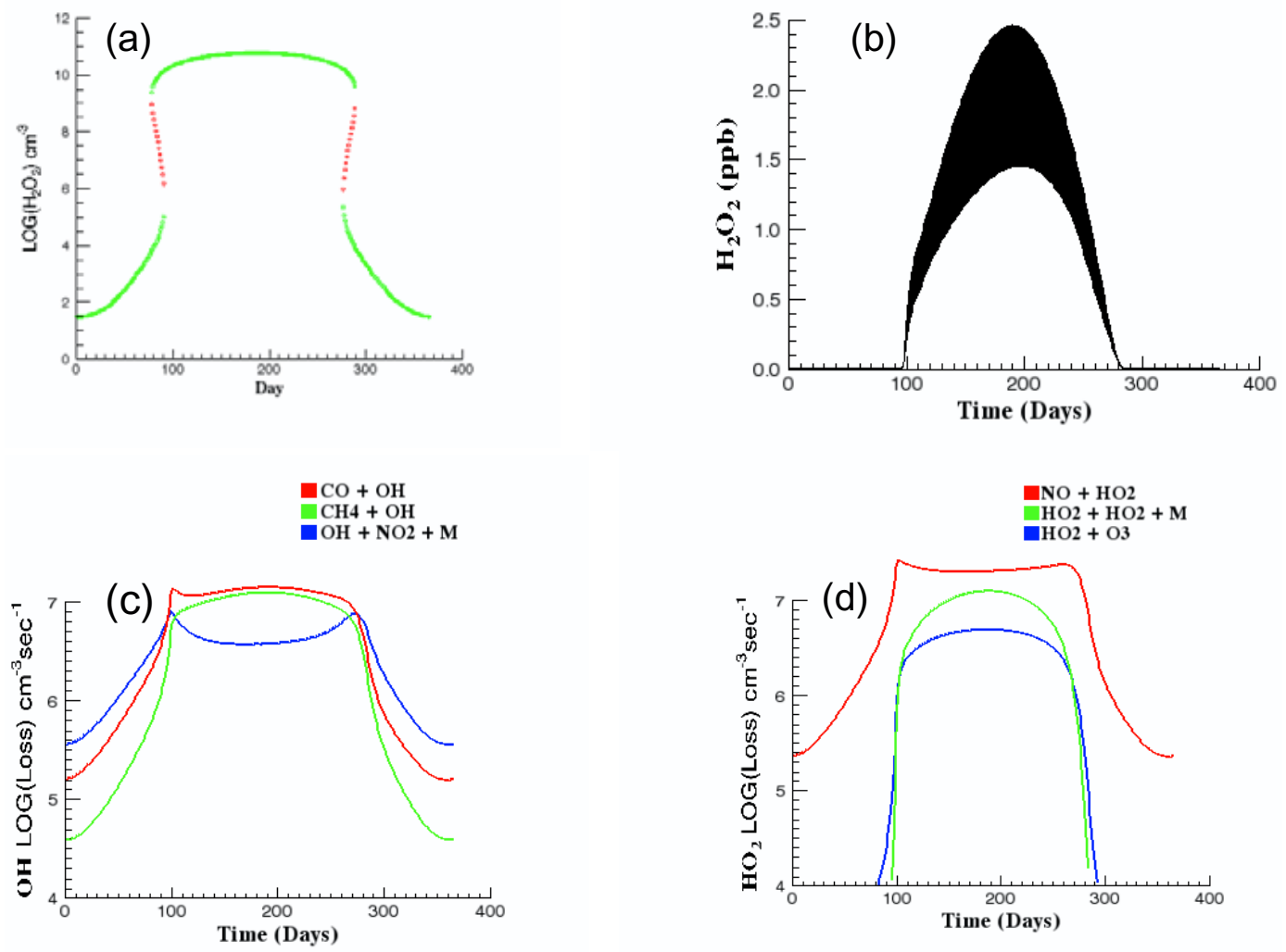

Fig. 3. Steady-state (a) and time-dependent (b) and (c) calculations for $\mathrm{S}_{\mathrm{NO}}$ of $2 \times 10^{6} \mathrm{~cm}^{-3} \mathrm{~s}^{-1}$. The summer to winter $\mathrm{NO}_{\mathrm{X}}$ range in this model is 0.5 to $5 \mathrm{ppb}$. Part (c) shows that $\mathrm{HNO}_{3}$ formation (blue) dominates $\mathrm{CO}$ (red) and $\mathrm{CH}_{4}$ (green) oxidation in winter, while panel (d) shows the $\mathrm{HO}_{2}$ switch (Fig. 1) favors ozone production (red) over loss (blue).

to 1 April) and days 275 to 288 in the fall (2-15 October). The stable high- $\mathrm{NO}_{\mathrm{x}}$ (winter) and low- $\mathrm{NO}_{\mathrm{x}}$ (summer) regions are separated by sequences of unstable states shown in red. The instability in the steady-state mode corresponds relatively well to the times at which the dominant pathway for $\mathrm{OH}$ reaction, Fig. 3c, switches from nitric acid formation to hydrocarbon oxidation in the spring (day 80, 21 March) and back to nitric acid formation in the fall (day 290, 17 October). The spring increase in time-dependent mixing ratio, Fig. 3b, is most rapid between days 78 and 86 (19-27 March) in reasonable agreement with the switch from high to low- $\mathrm{NO}_{\mathrm{x}}$ conditions indicated by the steady-state model (Fig. 3a) and the comparison of $\mathrm{OH}$ reaction rates (Fig. 3c). During this time the peroxide mixing ratio increases from about $1 \mathrm{ppt}$ to 300 ppt. Thereafter a slower increase to the summer maximum of about $2.5 \mathrm{ppb}$ takes place. In the fall, the most rapid decrease in peroxide mixing ratio occurs between days 280 and 310 (2 October to 6 November) and is roughly the opposite of the spring increase, but over a longer time span. $\mathrm{HO}_{2}$ loss rates shown in Fig. 3d indicate that the summer low- $\mathrm{NO}_{\mathrm{x}}$ regime is ozone producing throughout. It also indicates, in contrast with the model in Fig. 2, that significant $\mathrm{H}_{2} \mathrm{O}_{2}$ production occurs only in summer.
As $\mathrm{S}_{\mathrm{NO}}$ is increased from the value used in Fig. 3, the bistable regions in the steady-state calculation lengthen and the neck of the mushroom is pinched inward.

The changes resulting from further increase in $\mathrm{S}_{\mathrm{NO}}$ are seen in Fig. 4a where the spring and fall bistable regions extend from days 95 to 158 (5 April to 7 June) and 205 to 268 (24 July to 25 September). The NO source used in the model shown in Fig. 4 is $S_{\mathrm{NO}}=3.73 \times 10^{6}$. This value is chosen for display since it is the highest $\mathrm{S}_{\mathrm{NO}}$ considered for which the time-dependent model shows high to low- $\mathrm{NO}_{\mathrm{x}}$ transitions.

It is a consequence of the model design that the steadystate profile is symmetric about mid-summer. However, the steady-state calculation suggests that its time-dependent analogue will not be. As days progress through the seasons, a transition from winter to summer conditions will not be forced until 7 June and the corresponding return to winter not forced until 25 September. We thus expect a shift of the timedependent profile towards the fall side of summer, the shift being greater the more pronounced the pinch in the neck of the mushroom. This is apparent in Fig. 4b along with a much more dramatic asymmetry in the rates of the spring increase and fall decrease of $\left[\mathrm{H}_{2} \mathrm{O}_{2}\right]$. The high to low- $\mathrm{NO}_{\mathrm{x}}$ transition in the time-dependent $\mathrm{H}_{2} \mathrm{O}_{2}$ profile begins on day 195 (14 July) and is completed in 3 days. The mixing ratio increase 

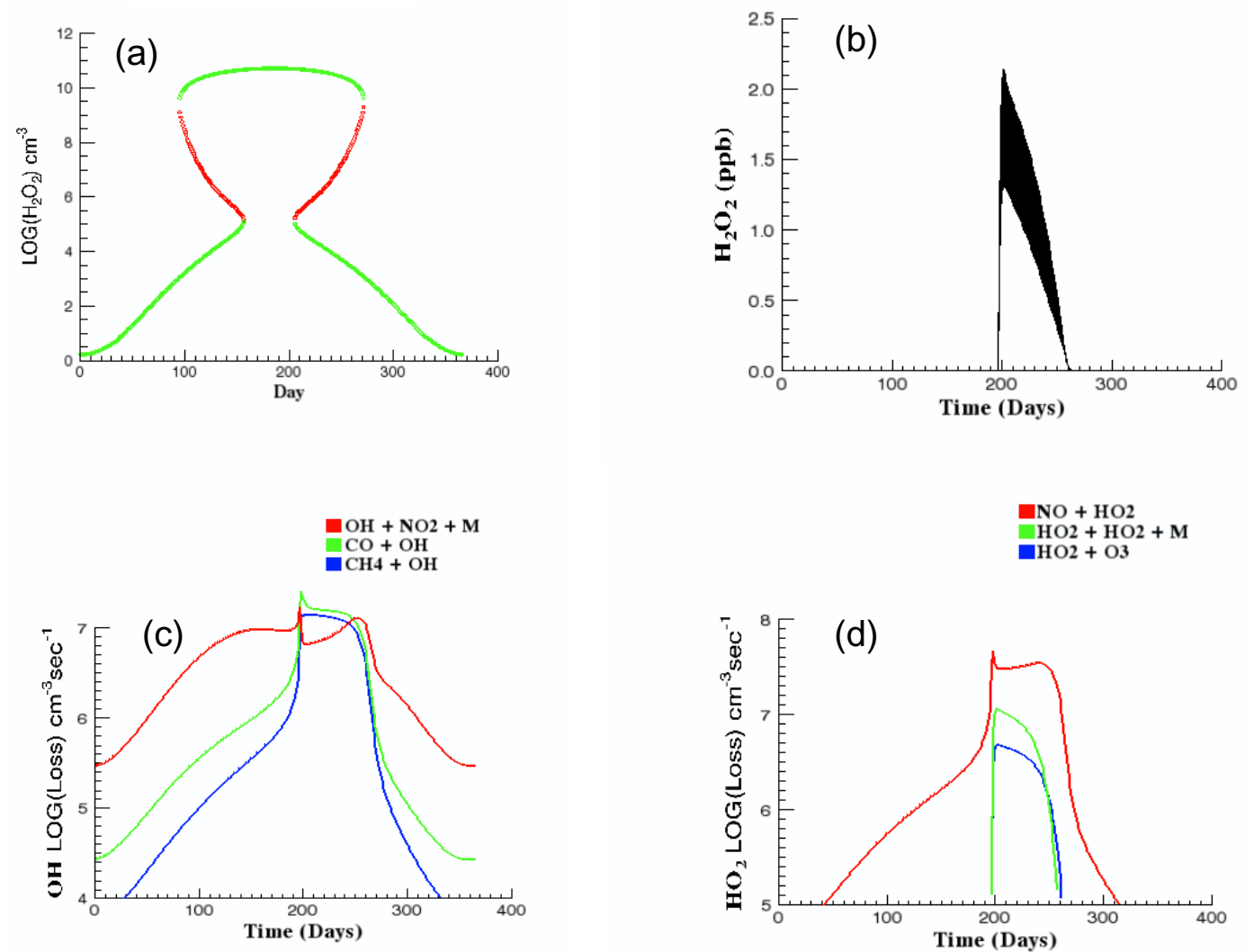

Fig. 4. Similar to Figs. 2 and 3, but with an assumed $\mathrm{S}_{\mathrm{NO}}$ of $3.73 \times 10^{6} \mathrm{~cm}^{-3} \mathrm{~s}^{-1}$. The summer to winter range of $\mathrm{NO}_{\mathrm{x}}$ is 2 to $70 \mathrm{ppb}$. Part (c) shows that $\mathrm{HNO}_{3}$ formation (now in red) dominates $\mathrm{CO}$ (green) and $\mathrm{CH}_{4}$ (blue) oxidation except for a brief period of about 52 days in summer. In panel (d) the dominance of $\mathrm{HO}_{2}$ reaction with $\mathrm{NO}$ (red) rather than $\mathrm{O}_{3}$ (blue) facilitates ozone production in the low $\mathrm{NO}_{\mathrm{x}}$ regime.

in this period is from $0.5 \mathrm{ppt}$ to $1.7 \mathrm{ppb}$. The much less abrupt fall transition occurs between days 250 and 280 (7 September to 7 October). The mixing ratio decreases from $0.4 \mathrm{ppb}$ to 0.002 ppt during this 30 day interval. The difference in rapidity of spring and fall transitions is a consequence of the different mechanisms involved in $\mathrm{H}_{2} \mathrm{O}_{2}$ production (spring) and loss (fall) mechanisms. In spring, peroxide production is limited by the rapid radical reactions in the chain propagation phase, Reactions (3-5) in Sect. 2.1. In the fall its loss is limited by photolysis and reaction with the $\mathrm{OH}$ radical. These loss reactions are included in the model, but are not part of the simplified scheme given by Reactions (1) to (7). The switch between nitric acid formation and hydrocarbon $\left(\mathrm{CO}\right.$ and $\left.\mathrm{CH}_{4}\right)$ oxidation by $\mathrm{OH}$ occurs on days 195 and 248 (Fig. 4c) corresponding to the transitions described for the $\mathrm{H}_{2} \mathrm{O}_{2}$ mixing ratio. The chemistry, as expected, is ozone producing throughout the short low- $\mathrm{NO}_{\mathrm{x}}$ portion of summer (Fig. 4d). The $\mathrm{NO}_{\mathrm{x}}$ range in this model is about $70 \mathrm{ppb}$ (winter/spring) to $2 \mathrm{ppb}$ (summer), characteristic of rural to urban-suburban regions (National Research Council, 1992). The correspondence between steady-state and timedependent models in the time of the spring transition is not as close as that shown in Fig. 3. Although, according to the steady-state model, a transition should be forced by 7 June it does not occur in the time-dependent case until 14 July.

Figure 5 shows the model calculations for $\mathrm{S}_{\mathrm{NO}}=4.0 \times 10^{6} \mathrm{~cm}^{-3} \mathrm{~s}^{-1}$ and a corresponding summer to winter $\left[\mathrm{NO}_{\mathrm{x}}\right]$ of 75 to $130 \mathrm{ppb}$. This is the next higher source value from that considered in Fig. 4. The mushroom configuration seen in Fig. 3a and 4a has now become a continuous branch of high $\mathrm{NO}_{\mathrm{x}}$ states (Fig. 5a) that persists throughout the year and an isolated branch consisting of low- $\mathrm{NO}_{\mathrm{x}}$ summer values and unstable states. An isolated branch of solutions as shown in Fig. 5a is called an "isola" (Grey and Scott, 1990).

For this and higher $\mathrm{NO}$ source and $\left[\mathrm{NO}_{\mathrm{x}}\right]$ background values, the summer low- $\mathrm{NO}_{\mathrm{x}}$ states are inaccessible from the time-dependent model. This model remains in a high$\mathrm{NO}_{\mathrm{x}}$ state throughout the year as indicated by the low $\mathrm{H}_{2} \mathrm{O}_{2}$ mixing ratios (Fig. 5b) and the dominance of nitric acid formation over hydrocarbon oxidation (Fig. 5c). The units in Fig. $5 b$ are parts per quadrillion (ppqd). The $\mathrm{HO}_{2}$ ozone Production/Loss switch remains in the production position (Figs. 5d and 1), but this is irrelevant since oxidant 

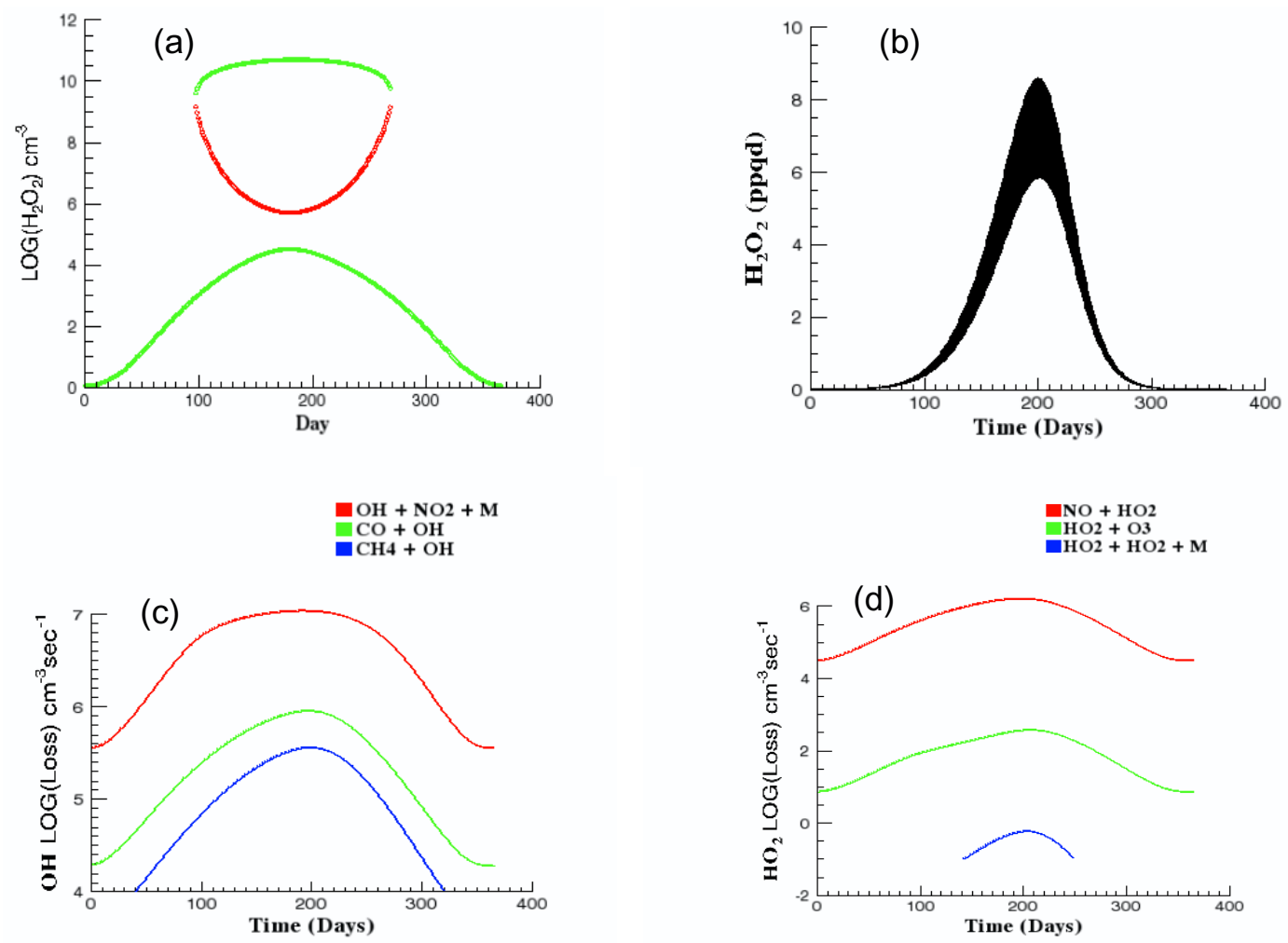

Fig. 5. Similar to Figs. 2-5 but for an assumed $\mathrm{S}_{\mathrm{NO}}=4.0 \times 10^{6} \mathrm{~cm}^{-3} \mathrm{~s}^{-1}$. The summer to winter $\mathrm{NO}_{\mathrm{x}}$ range is 75 to $130 \mathrm{ppb}$. The $\mathrm{OH}$ reaction rates in part (c) indicate high- $\mathrm{NO}_{\mathrm{x}}$ dominance throughout the year. In this high- $\mathrm{NO}_{\mathrm{x}}$ regime $\mathrm{H}_{2} \mathrm{O}_{2}$ production is negligible (d).

production has been effectively cut off by the switch from low to high- $\mathrm{NO}_{\mathrm{x}}$ chemistry (Fig. 1, OH box). Figure $5 \mathrm{~d}$ shows the negligible peroxide production rate. As $\mathrm{S}_{\mathrm{NO}}$ increases further, the isola shown in Fig. 5a shrinks and finally disappears at $\mathrm{S}_{\mathrm{NO}} \approx 1.5 \times 10^{7} \mathrm{~cm}^{-3} \mathrm{~s}^{-1}$.

The $\mathrm{NO}_{\mathrm{x}}$ mixing ratios in this model are characteristic of the urban troposphere (National Research Council, 1992), but the overall model chemistry is not since no significant NMHC are included. In a more comprehensive chemical model, $\mathrm{NMHC}$ would result in greater $\mathrm{HO}_{\mathrm{x}}$ production and defer an annually dominant high- $\mathrm{NO}_{\mathrm{x}}$ regime to higher background $\mathrm{NO}_{\mathrm{x}}$ levels. For example, the model study of Honoré et al. (2000) contains a more realistic urban chemistry. These authors employ a chemistry-transport box model and, for stagnant conditions, find two distinct diurnal equilibria for $\mathrm{NO}_{\mathrm{x}}$ emissions $\sim$ a few times $10^{7} \mathrm{~cm}^{-3} \mathrm{~s}^{-1}$ (this estimate is based on their reported maximum $\mathrm{NO}_{\mathrm{x}}$ emissions, $\mathrm{NO}_{\mathrm{x}}$ emission weight and their maximum mixed layer height of $1.5 \mathrm{~km}$ ). Their bistable regime occurs at $\mathrm{NO}_{\mathrm{x}}$ source values that would result in only high- $\mathrm{NO}_{\mathrm{x}}$ solutions in the current model. This effect is also seen in many other models of urban photochemistry in which contour plots of $\mathrm{O}_{3}$ (or $\mathrm{O}_{3}$ production) as a function of $\mathrm{NO}_{\mathrm{x}}$ and $\mathrm{VOC}$ (volatile organic compounds) mixing ratios show the low- $\mathrm{NO}_{\mathrm{x}}$ (or $\mathrm{NO}_{\mathrm{x}}$-sensitive or $\mathrm{NO}_{\mathrm{x}}$-limited) to high- $\mathrm{NO}_{\mathrm{x}}$ (or VOC-sensitive or VOClimited) transition moving to higher $\mathrm{NO}_{\mathrm{x}}$ values as VOC in- creases. Examples may be found in Sillman (1999) and Tonnesen (1999).

The progression of steady-state solutions shown in Figs. 2a-5a are slices through a three-dimensional (Day, $\mathrm{S}_{\mathrm{NO}},\left[\mathrm{H}_{2} \mathrm{O}_{2}\right]$ ) surface for selected (Day, $\left[\mathrm{H}_{2} \mathrm{O}_{2}\right]$ ) planes perpendicular to the NO source axis. The full set of solutions is shown by the bifurcation surface in Fig. 6 . In this figure the Day axis ranges from days 0 through 400 increasing away from the vertex. The NO source axis, labeled $\log \left(\mathrm{S} / \mathrm{cm}^{3} *_{\mathrm{s}}\right.$ ), ranges from 8 to 4 decreasing away from the vertex and the $\log \left(\mathrm{H}_{2} \mathrm{O}_{2} / \mathrm{cm}^{3}\right)$ concentrations range through twelve orders of magnitude. The top part of this figure, furthest from the day axis, represents the purely low- $\mathrm{NO}_{\mathrm{x}}$ solutions corresponding to situations like that shown in Fig. 2a. Since the annual range of low- $\mathrm{NO}_{\mathrm{x}}$ peroxide values is only about $2 \mathrm{ppb}$, this portion of Fig. 6 has a flat appearance. Slices taken with a plane parallel to the plane defined by the (Day, $\left.\log \left(\mathrm{H}_{2} \mathrm{O}_{2}\right)\right)$ axes generate the profiles in Figs. 2a through 5a. The rightmost such plane generates the purely low- $\mathrm{NO}_{\mathrm{x}}$ profile of Fig. 2a. As this plane is moved towards the front of the figure, the pure low- $\mathrm{NO}_{\mathrm{x}}$ solutions give way to mushrooms with increasingly pinched necks, then to a combination of high- $\mathrm{NO}_{\mathrm{x}}$ solution branches and low- $\mathrm{NO}_{\mathrm{x}}$ isolas and finally to a single branch of high- $\mathrm{NO}_{\mathrm{x}}$ solutions. These last are along the lower part of the figure nearest the day axis. 


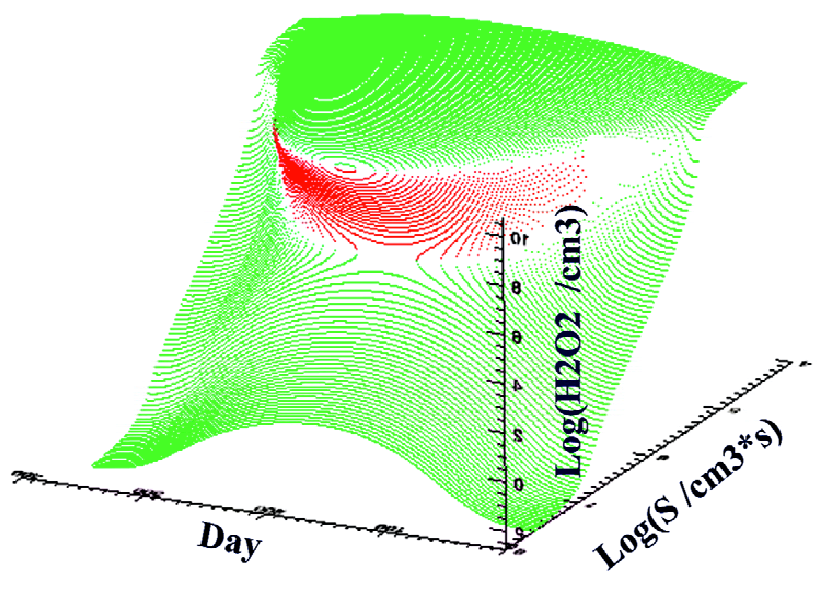

Fig. 6. $\mathrm{H}_{2} \mathrm{O}_{2}$ bifurcation surface. Selected slices through this surface parallel to the plane defined by the Day, $\log \left(\mathrm{H}_{2} \mathrm{O}_{2}\right)$ axes generate the profiles shown in Figs. 2-5.

As stated in the preceding text, to test the robustness of the results some runs have been made with changes in selected parameter values and model reactions. Interesting variants on the above model are provided by cases in which, as $\mathrm{S}_{\mathrm{NO}}$ is increased from low values, a high- $\mathrm{NO}_{\mathrm{x}}$ isola, lying under the branch of low- $\mathrm{NO}_{\mathrm{x}}$ states, first develops in winter. This isola grows and merges with the low- $\mathrm{NO}_{\mathrm{x}}$ states to form a single mushroom branch, similar to Figs. $3 \mathrm{a}$ and $4 \mathrm{a}$. The neck of the mushroom then pinches off to leave a continuous branch of high- $\mathrm{NO}_{\mathrm{x}}$ states and a low- $\mathrm{NO}_{\mathrm{x}}$ summer isola as in Fig. 5a. An example of such a system is a model consisting only of Reactions (1-7) supplemented by $\mathrm{HNO}_{3}$ deposition and $\mathrm{H}_{2} \mathrm{O}_{2}$ deposition, photolysis and reaction with $\mathrm{OH}$. The results regarding the correspondence between steady-state bifurcations and time-dependent transitions in the model remain unaltered.

\subsection{Annual Variation of Selected Species}

Table 3 shows the approximate winter to summer change in noon mixing ratio for selected species in the time-dependent models shown in Figs. 2b-5b. The corresponding labels in the table are F2-F5. These models are characterized by increasing assumed NO source values and hence by increasing $\mathrm{NO}_{\mathrm{x}}$ mixing ratios.

Model F2 is typical of a low- $\mathrm{NO}_{\mathrm{x}}$, ozone destruction environment. Ozone in this case is higher in winter than summer since the enhanced summer photolysis acts to destroy it. This type of annual ozone cycle is seen in the remote marine troposphere at Cape Grim (Ayers et al., 1996). In this environment the seasonal variation of $\mathrm{O}_{3}$ is negatively correlated with $\mathrm{H}_{2} \mathrm{O}_{2}$ and positively correlated with $\mathrm{CO}$.
Table 3. Average winter (W) and summer (S) values in selected species mixing ratios (all in ppb). Models F2 through F5 correspond to the calculations shown in Figs. 2-5.

\begin{tabular}{ccccccccc}
\hline Model & \multicolumn{2}{c}{ F2 } & \multicolumn{2}{c}{ F3 } & \multicolumn{2}{c}{ F4 } & \multicolumn{2}{c}{ F5 } \\
Season & W & S & W & S & W & S & W & S \\
\hline $\mathrm{O}_{3}$ & 75 & 55 & 70 & 85 & 20 & 100 & 40 & 40 \\
$\mathrm{NO}_{\mathrm{x}}$ & .08 & .04 & 5 & 0.5 & 70 & 2 & 130 & 75 \\
$\mathrm{CO}$ & 95 & 70 & 90 & 55 & 130 & 55 & 130 & 125 \\
\hline
\end{tabular}

\section{Discussion}

As noted in the introduction to the paper, there are two sets of $\mathrm{H}_{2} \mathrm{O}_{2}$ measurements that cover one or more annual cycles and are thus of particular interest to this model study. One of these is the Cape Grim, Tasmania measurements of Ayers et al. (1996), the other the measurements of Sakugawa and Kaplan (1989) at Westwood, CA in the Los Angeles basin. These clearly represent different pollution backgrounds. The Cape Grim observations are characteristic of clean maritime air while those near Los Angeles are more polluted having mean $\mathrm{NO}_{\mathrm{x}}$ over the measurement period of $36 \mathrm{ppb}$.

The Cape Grim measurements are presented as hourly average concentrations of total peroxide between early February 1991 and late March 1992. The monthly mean concentrations show a seasonal cycle with a range of values from $\sim 200 \mathrm{ppt}$ in winter to $1.4 \mathrm{ppb}$ in summer. The background atmosphere is low- $\mathrm{NO}_{\mathrm{x}}$, ozone-destroying throughout the year as evidenced by the high winter and low summer ozone concentrations. These data are thus comparable to the low- $\mathrm{NO}_{\mathrm{x}}$ cycle shown in Fig. 2. The summer maximum in Fig. $2 \mathrm{~b}$ is larger than that in the Cape Grim data, 2 ppb of $\mathrm{H}_{2} \mathrm{O}_{2}$ as compared to the monthly mean $1.4 \mathrm{ppb}$ total peroxide. Maximum total peroxide concentrations during summer at Cape Grim did sometimes exceed $2 \mathrm{ppb}$. The NO concentrations during the measurement period are unknown, but a value of $3 \mathrm{ppt}$ was assumed by Ayers et al. (1996) in modeling their data. If this is reasonably accurate then the range of 40 to $80 \mathrm{ppt}$ in the model shown in Fig. 2 would be expected to result in higher peroxide. The principal feature to note in both the model and data is the lack of a sharp winter/summer transition in $\mathrm{H}_{2} \mathrm{O}_{2}$ concentrations. The Cape Grim monthly mean peroxide values as well as the model calculations presented by the authors, both shown in their Fig. 4, show a gradual rise from the July winter low to the December summer high concentrations. The change may be described as following a more or less sinusoidal curve.

The Sakugawa and Kaplan data cover the annual variation of $\mathrm{H}_{2} \mathrm{O}_{2}$ over three years from August 1985 through September 1988 at Westwood, CA. Two complete annual cycles for years 1986 and 1987 are shown as well as part of the 1985 and 1988 cycles. The $\mathrm{H}_{2} \mathrm{O}_{2}$ concentrations are 4-hour averages (1200-1600 hr) taken on selected days (clear to partly 
cloudy skies) during each month. Mean, maximum and minimum values of $\mathrm{NO}_{\mathrm{x}}, \mathrm{NMHC}$ and other pollutants over the entire observation period are reported. The mean $\mathrm{NO}_{\mathrm{x}}$ level of $36 \mathrm{ppb}$ is within the range of values in the model calculations shown in Figs. 3 and 4. In contrast to the Cape Grim data and the low- $\mathrm{NO}_{\mathrm{x}}$ cycle shown in Fig. 2, the Westwood cycles show rapid changes between winter and summer conditions, especially in the spring. For example, the $1986\left[\mathrm{H}_{2} \mathrm{O}_{2}\right]$ values remain relatively low until June at which time a change to summer concentrations occurs. The temporal resolution of the data doesn't permit an evaluation of the time taken for this transition, but it is clearly completed in the month of June. The summer data for this particular year are sparse, but the return to winter concentrations is completed by the beginning of September. The overall appearance of this cycle is that of a "spike", sharper than the model profile in Fig. $4 \mathrm{~b}$. There is no obvious difference in the rapidity of spring and fall transitions in the 1986 cycle, but there are fewer data points by which to judge than in the following year. The 1987 cycle also shows a rapid winter to summer transition beginning in April with some high $\mathrm{H}_{2} \mathrm{O}_{2}$ values extending into October. Here, there is a suggestion of a difference in rapidity with which the spring and fall transitions occur with high $\mathrm{H}_{2} \mathrm{O}_{2}$ values extending, with decreasing frequency, into October.

Some features of the Sakugawa and Kaplan time series differ from the profiles shown in Figs. 3 and 4 in the present model. Foremost among these is the range of winter to summer values. Observed summer $\left[\mathrm{H}_{2} \mathrm{O}_{2}\right]$ had a mean value $\sim 1.0 \mathrm{ppb}$ while the model calculations reach or exceed $2 \mathrm{ppb}$ in any model with a low- $\mathrm{NO}_{\mathrm{x}}$ summer. Observed winter $\left[\mathrm{H}_{2} \mathrm{O}_{2}\right]$ had a mean value $\sim 0.2 \mathrm{ppb}$ whereas it is essentially 0 in the model calculations with a high- $\mathrm{NO}_{\mathrm{x}}$ winter. Since the NMHC chemistry considered in the model is limited it is probable that winter production of $\mathrm{H}_{2} \mathrm{O}_{2}$ resulting from NMHC oxidation by $\mathrm{O}_{3}$ and $\mathrm{NO}_{3}$ is underestimated. In a model study based on Westwood conditions Sakugawa et al. (1990) calculated maximum $\mathrm{H}_{2} \mathrm{O}_{2}$ concentrations of $\sim 3.2 \mathrm{ppb}$ in summer (July) and $0.05 \mathrm{ppb}$ in winter (January).

The Westwood CA data do not contain enough information to calculate radical production and loss rates like those carried out by Kleinman (1991) thus confirming a high- $\mathrm{NO}_{\mathrm{x}}$ winter to low- $\mathrm{NO}_{\mathrm{x}}$ summer transition. Nonetheless, the morphological differences in the clean air Cape Grim observations and the more polluted Westwood observations and the similar changes in model profiles shown in this paper as $\mathrm{NO}_{\mathrm{x}}$ background increases (Figs. $2 b$ through $4 b$ ) suggest that such transitions occur.

\section{Summary and conclusions}

This paper has explored the relationship between the chemical instability seen in steady-state tropospheric models and corresponding time-dependent behavior. The objective has been to see whether the observed changes in $\mathrm{H}_{2} \mathrm{O}_{2}$ concen- trations from summer to winter may, under some circumstances, be interpreted as a manifestation of chemical instability. The main features shown by the model calculations are the following: first, an increase in the sharpness of the winter high- $\mathrm{NO}_{\mathrm{x}}$ to summer low- $\mathrm{NO}_{\mathrm{x}}$ transition as $\mathrm{NO}_{\mathrm{x}}$ concentration increases; second, an asymmetry in both rapidity and time of the spring and fall transitions, the time of transition shifting towards the fall side of summer as $\mathrm{NO}_{\mathrm{x}}$ levels increase; and third, a correspondence between time-dependent high/low $\mathrm{NO}_{\mathrm{x}}$ transitions and instability in the underlying (steady-state) chemistry.

The data sets discussed above lend support to the first of these features. The change from winter low to summer high peroxide concentrations is much more gradual in the clean air observations of Ayers et al. (1996) than in the Sakugawa and Kaplan (1989) observations near Los Angeles. The 1987 annual cycle observed by Sakugawa and Kaplan (1989) are compatible with the second feature, but this is less clear in the 1986 cycle. Finally, the third feature would require additional observations sufficient to calculate radical production and loss rates. The correspondence cited in the third feature is not an observable, but is important in interpreting observations of change in peroxide concentrations as indicative of bistability in the chemical system.

The rapid growth of $\left[\mathrm{H}_{2} \mathrm{O}_{2}\right]$ predicted for spring high to low- $\mathrm{NO}_{\mathrm{x}}$ transitions would be a more definitive indicator of instability than would the slower $\left[\mathrm{H}_{2} \mathrm{O}_{2}\right]$ decay in the fall low to high- $\mathrm{NO}_{\mathrm{x}}$ transition. Shorter transition times correspond to higher $\mathrm{S}_{\mathrm{NO}}$, and thus higher background $\mathrm{NO}_{\mathrm{x}}$ values. For NO source values greater than $2 \times 10^{6} \mathrm{~cm}^{-3} \mathrm{~s}^{-1}$, the spring transition in the model reported here results in $\left[\mathrm{H}_{2} \mathrm{O}_{2}\right]$ increases from $<10 \mathrm{ppt}$ (i.e. unobservable) to a few hundred ppt in periods of 3 to 7 days. Ideally, observations would be carried out over one or more annual cycles in a region in which winter $\left[\mathrm{NO}_{\mathrm{x}}\right]$ is sufficient to govern a high- $\mathrm{NO}_{\mathrm{x}}$ regime. A persistent interval, days to weeks, of below detection limit to perhaps tens of ppt peroxide concentrations followed by a change over an interval of a week or less to a period of detectable and rapidly increasing concentrations would suggest that bifurcations in the chemistry might be invoked as an explanation. On the other hand, a relatively smooth transition such as that shown in the Cape Grim data (Ayers et al., 1996) or in the model profile of Fig. 2b would indicate that such a nonlinear effect does not occur. If the observed data set included additional observations sufficient to compute radical production and loss rates, $\mathrm{CO}, \mathrm{CH}_{4}, \mathrm{NMHC}$, $\mathrm{O}_{3}, \mathrm{H}_{2} \mathrm{O}$, and $\mathrm{NO}_{\mathrm{x}}$, as well as meteorological variables, a definitive conclusion might be possible.

The model used in this study, in common with many models, gives results that are concise and readily interpretable. Nature is not so accommodating. Clouds and fogs form and dissipate, rain falls and winds blow. All such events influence the concentration of a moderately long-lived and soluble species such as $\mathrm{H}_{2} \mathrm{O}_{2}$. The result is a degree of variability that is sure to complicate any attempt to relate observations 
to the consequences of chemical influences. The greatest difficulty in carrying out a program of $\mathrm{H}_{2} \mathrm{O}_{2}$ observations would probably be separating the effects of transport from local photochemistry. However, although the Sakugawa and Kaplan (1989) observations show considerable scatter, there is a clear winter/summer separation so the possibility of using such measurements, along with the additional observations noted above, to definitively establish instability or its absence in atmospheric photochemistry cannot be ruled out. Should difficulties in using $\mathrm{H}_{2} \mathrm{O}_{2}$ prove insurmountable it might still be possible to look for evidence of chemical instability in the transitions of a shorter-lived species, such as $\mathrm{OH}$, that would quickly relax to the local chemistry following transport events.

Chemical instability is a mathematical characteristic of photochemical models. Due to the magnitude of the changes induced by such instability the question of the existence of atmospheric consequences should be pursued.

Edited by: P. Monks

\section{References}

Atkinson, R., Baulch, D. L., Hampson , R. F. Jr., Kerr, J. A., and Troe, J.: Evaluated kinetic and photochemical data for atmospheric chemistry, J. Phys. Chem. Ref. Data 21, suppl. IV, 11251568, 1992.

Ayers, G. P., Penkett, S. A., Gillett, R. W., Bandy, B., Galbally, I. E., Meyer, C. P., Ellsworth, C. M., Bentley, S. T., and Forgan, B. W.: The annual cycle of peroxides and ozone in marine air at Cape Grim, Tasmania, J. Atmos. Chem., 23, 221-252, 1996.

Barker, J. R.: A Brief Introduction to Atmospheric Chemistry, in Progress and Problems, in Atmospheric Chemistry, edited by Barker, J. R., pp. 1-33, World Scientific, Singapore, 1995.

Bottenheim, J. W. and Shepherd, M. F.: $\mathrm{C}_{2}-\mathrm{C}_{6}$ Hydrocarbon measurements at four rural locations across Canada, Atmos. Environ., 29, 647-664, 1995.

Crutzen, P. J. and Zimmermann, P. H.: The changing photochemistry of the troposphere, Tellus, 43AB, 136-151, 1991.

DeMore, W. B., Sander, S. P., Golden, D. M., Hampson, R. F., Kurylo, M. J., Howard, C. J., Ravishankara, A. R., Kolb, C. E., and Molina, M. J.: Chemical kinetics and photochemical data for use in stratospheric modeling, JPL publication 97-4, 1997.

Dimitroulopoulou, C. and Marsh, A. R. W.: Modelling studies of $\mathrm{NO}_{3}$ nighttime chemistry and its effects on subsequent ozone formation, Atmos. Environ., 31, 3041-3057, 1997.

Field, R. J., Hess, P. G., Kalachev, L. V., and Madronich, S.: Characterization of oscillation and a period-doubling transition to chaos reflecting dynamic instability in a simplified model of tropospheric chemistry, J. Geophys. Res., 102D, 7553-7565, 2001.

Fox, J. L., Wofsy, S. C., McElroy, M. B., and Prather, M. J.: A Stratospheric Chemical Instability, J. Geophys. Res., 87, 11 126$11132,1982$.

Gnauk, T., Rolle, W., and Spindler, G.: Diurnal variations of atmospheric hydrogen peroxide concentrations in Saxony (Germany), J. Atmos. Chem., 27, 79-103, 1997.
Grey, P. and Scott, S. K.: Chemical Oscillations and Instabilities: Non-linear Chemical Kinetics, Oxford Science Publications, New York, 1990.

Hameed, S., Pinto, J. P., and Stewart, R. W.: Sensitivity of the Predicted $\mathrm{CO}-\mathrm{OH}-\mathrm{CH}_{4}$ Perturbation to Tropospheric $\mathrm{NO}_{\mathrm{x}}$ Concentrations, J. Geophys. Res., 84, 763-768, 1979.

Hauglustaine, D. A., Granier, C. Brasseur, G. P., and Megie, G.: The importance of atmospheric chemistry in the calculation of radiative forcing on the climate system, J. Geophys. Res., 99, 1173-1186, 1994.

Hindmarsh, A. C.: Odepack, a systematized collection of ode solvers, in Scientific Computing, edited by Stepleman, R. S., et al., pp. 55-64, North-Holland, Amsterdam, 1983.

Holton, J. R. and Lelieveld, J.: Stratosphere-Troposphere Exchange and its role in the budget of tropospheric ozone, in Proceedings of the NATO Advanced Research Workshop, Clouds, Chemistry and Climate, edited by Crutzen, P. and Ramanathan, V., pp. 173190, Ringberg, Germany, 1994.

Honoré, C., Vautard, R., and Beekmann, M.: Photochemical regimes in urban atmospheres: The influence of dispersion, Geophys. Res. Lett., 27, 1895-1898, 2000.

Jacob, D. J., Horowitz, L. W., Munger, J. W., Heikes, B. G., Dickerson, R. R., Artz, R. S., and Keene, W. C.: Seasonal transition from $\mathrm{NO}_{\mathrm{x}}$ to hydrocarbon-limited conditions for ozone production over the eastern United States in September, J. Geophys. Res., 100, 9315-9325, 1995.

Kalachev, L. V. and Field, R. J.: Reduction of a model describing ozone oscillations in the troposphere, J. Atmos. Chem., 39, 6593, 2001.

Kleinman, L. I.: Seasonal Dependence of Boundary Layer Peroxide Concentrations: The Low and High $\mathrm{NO}_{\mathrm{x}}$ Regimes, J. Geophys. Res., 96, 20 721-20 733, 1991.

Kleinman, L. I.: Low and High $\mathrm{NO}_{\mathrm{x}}$ tropospheric photochemistry, J. Geophys. Res., 99, 16831-16838, 1994.

Konovalov, I. B., Feigin, A. M., and Mukhina, A. Y.: Toward understanding of the nonlinear nature of atmospheric photochemistry: Multiple equilibrium states in the high-latitude lower stratosphere photochemical system, J. Geophys. Res., 104, 36693689, 1999.

Lee, M., Heikes, B. G., and O'Sullivan, D. W.: Hydrogen peroxide and organic hydroperoxide in the troposphere: a review, Atmos. Environ., 34, 3475-3494, 2000.

Lelieveld, J., Peters, W., Dentener, F. J., and Krol, M. C.: Stability of tropospheric hydroxyl chemistry, J. Geophys. Res., 107(D23) doi:10.1029/2002JD002272, 2002.

Levy, H.: Normal atmosphere: Large radical and formaldehyde concentrations predicted, Science, 173, 141-143, 1971.

Madronich, S.: Photodissociation in the atmosphere 1. Actinic flux and the effect of ground reflectance and clouds, J. Geophys. Res., 92, 9740-9752, 1987.

National Research Council: Rethinking the ozone problem in urban and regional air pollution, National Academy Press, Washington D.C., 1992.

Olivier, J. G. J., Bloos, J. P. J., Berdowski, J. J. M., Visschedijk, A. J. H., and Bouwman, A. F.: A 1990 global emission inventory of anthropogenic sources of carbon monoxide on $1^{\circ} \times 1^{\circ}$ developed in the framework of EDGAR/GEIA, Chemosphere: Global Change Science, 1, 1-17, 1999. 
Paulson, S. E.: The Tropospheric Oxidation of Organic Compounds: Recent developments in $\mathrm{OH}, \mathrm{O}_{3}$, and $\mathrm{NO}_{3}$ Reactions with Isoprene and Other Hydrocarbons, in Progress and Problems in Atmospheric Chemistry, edited by Barker, J. R., pp. 111144, World Scientific, Singapore, 1995.

Poppe, D., Wallasch, M., and Zimmermann, J.: The dependence of the concentration of $\mathrm{OH}$ on its precursors under moderately polluted conditions: a model study, J. Atmos. Chem., 16, 61-78, 1993.

Prather, M. J., McElroy, M. B., Wofsy, S. C., and Logan, J. A.: Stratospheric Chemistry: Multiple Solutions, Geophys. Res. Lett., 6, 163-164, 1979.

Prather, M. J.: Lifetimes and eigenstates in atmospheric chemistry, Geophys. Res. Lett., 21, 801-804, 1994.

Press, W. H., Teukolsky, S. A. Vetterling, W. T., and Flannery, B. P.: Numerical Recipes in FORTRAN The Art of Scientific Computing, 2nd Ed., Cambridge University Press, United Kingdom, 1992.

Sakugawa, H. and Kaplan, I. R.: $\mathrm{H}_{2} \mathrm{O}_{2}$ and $\mathrm{O}_{3}$ in the atmosphere of Los Angeles and its vicinity: factors controlling their formation and their role as oxidants of $\mathrm{SO}_{2}$, J. Geophys. Res., 94, $12957-$ 12973, 1989.

Sakugawa, H., Wangteng, T., Kaplan, I. R., and Cohen, Y.: Factors controlling the photochemical generation of gaseous $\mathrm{H}_{2} \mathrm{O}_{2}$ in the Los Angeles Atmosphere, Geophys. Res. Lett., 17, 93-96, 1990.

Sander, S. P., Friedl, R. R., Golden, D. M., Kurylo, M. J., Huie, R. E., Orkin, V. L., Moortgat, G. K., Ravishankara, A. R., Kolb, C.E., Molina, M. J., and Finlayson-Pitts, B. J.: Chemical Kinetics and Photochemical Data for Use in Atmospheric Studies, Evaluation Number 14, JPL Publication 02-25, 2003.

Sillman, S.: The relation between ozone, $\mathrm{NO}_{\mathrm{x}}$, and hydrocarbons in urban and polluted rural environments, Atmos. Environ., 33, 1821-1845, 1999.
Snow, J. A., Heikes, B. G., Merrill, J. T., Wimmers, A. J., Moody, J. L., and Cantrell, C. A.: Winter-spring evolution and variability of $\mathrm{HO}_{\mathrm{x}}$ reservoir species, hydrogen peroxide and methyl hydroperoxide, in the northern middle to high latitudes, J. Geophys. Res., 108(D4) doi:10.1029/2002JD002172, 2003.

Stewart, R. W., Hameed, S., and Pinto, J. P.: Photochemistry of tropospheric ozone, J. Geophys. Res., 82, 3134-3140, 1977.

Stewart, R. W., Hameed, S., and Matloff, G.: A model study of the effects of intermittent loss on odd nitrogen concentrations in the lower troposphere, J. Geophys. Res., 88, 10 697-10 707, 1983.

Stewart, R. W.: Multiple steady states in atmospheric chemistry, J. Geophys. Res., 98, 20 601-20 611, 1993.

Stewart, R. W.: Dynamics of the low to high $\mathrm{NO}_{\mathrm{x}}$ transition in a simplified tropospheric photochemical model, J. Geophys. Res., 100, 8929-8943, 1995.

Tie, X., Emmons, L., Horowitz, L., Brasseur, G., Ridley, B., Atlas, E., Stround, C., Hess, P., Klonecki, A., Madronich, S., Talbot, R., and Dibb, J.: Effect of sulfate aerosol on tropospheric $\mathrm{NO}_{\mathrm{x}}$ and ozone budgets: Model simulations and TOPSE evidence, J. Geophys. Res., 108(D4), 8364, doi:10.1029/2001JD001508, 2003.

Tinsley, M. R. and Field, R. J.: Dynamic instability in tropospheric photochemistry: An excitability threshold, Geophys. Res. Lett., 28, 4437-4440, 2001.

Tonnesen, G. S.: Effects of uncertainty in the reaction of the hydroxyl radical with nitrogen dioxide on model-simulated ozone control strategies, Atmos. Environ., 33, 1587-1598, 1999.

White, W. H. and Dietz, D.: Does the photochemistry of the troposphere admit more than one steady state?, Nature, 309, 242-244, 1984.

Yang, P. and Brasseur, G.: Dynamics of the oxygen-hydrogen system in the mesosphere 1. Photochemical equilibria and catastrophe, J. Geophys. Res., 99, 20 955-20 965, 1994. 